Article

\title{
Synthesis and Bioactivity Assessment of Novel Spiro Pyrazole-Oxindole Congeners Exhibiting Potent and Selective in vitro Anticancer Effects
}

\author{
Heba M. Abo-Salem ${ }^{1}{ }^{\circledR}$, Amr Nassrallah $^{2}$, Ahmed A.F. Soliman ${ }^{3}$, Manal S. Ebied ${ }^{1}$, \\ Mohamed E. Elawady ${ }^{4}$, Sayeda A. Abdelhamid ${ }^{4}$, Eslam R. El-Sawy ${ }^{1}{ }^{\circledR}$, Yazeed A. Al-Sheikh ${ }^{5}$ \\ and Mourad A. M. Aboul-Soud ${ }^{5, *(\mathbb{D})}$ \\ 1 Chemistry of Natural Compounds Department, National Research Centre, Dokki, 12622 Giza, Egypt; \\ hb_abosalem@yahoo.com (H.M.A.-S.); manalshaabanebied@gmail.com (M.S.E.); \\ eslamelsawy@gmail.com (E.R.E.-S.) \\ 2 Biochemistry Department, Faculty of Agriculture, Cairo University, 12613 Giza, Egypt; amotagly@cu.edu.eg \\ 3 Drug Bioassay-Cell Culture Laboratory, Pharmacognosy Department, National Research Center, Dokki, \\ 12622 Giza, Egypt; ashehabeldin2007@yahoo.com \\ 4 Microbial Biotechnology Department, National Research Centre, Dokki, 12622 Giza, Egypt; \\ mohamed_elawady82@yahoo.com (M.E.E.); sayeda.abdelrazek@yahoo.com (S.A.A.) \\ 5 Chair of Medical and Molecular Genetics Research, Department of Clinical Laboratory Sciences, College of \\ Applied Medical Sciences, King Saud University, P.O. Box 10219, Riyadh 11433, Saudi Arabia; \\ yalsheikh@ksu.edu.sa \\ * Correspondence: maboulsoud@ksu.edu.sa; Tel.: +966 11 4698617; Fax: +966 114693738
}

Received: 25 January 2020; Accepted: 29 February 2020; Published: 3 March 2020

\begin{abstract}
The present work aims to design and synthesize novel series of spiro pyrazole-3,3'-oxindoles analogues and investigate their bioactivity as antioxidant and antimicrobial agents, as well as antiproliferative potency against selected human cancerous cell lines (i.e., breast, MCF-7; colon, HCT-116 and liver, HepG-2) relative to healthy noncancerous control skin fibroblast cells (BJ-1). The mechanism of their cytotoxic activity has been also examined by immunoassaying the levels of key anti- and proapoptotic protein markers. The analytical and spectral data of the all synthesized target congeners were compatible with their structures. Synthesized compounds showed diverse moderate to powerful antimicrobial and antioxidant activities. Results of MTT assay revealed that seven synthesized compounds (i.e., 11a, 11b, 12a, 12b, 13b, 13c and 13h) particularly exhibited significant cytotoxicity against the three cancerous cell lines under investigation. Ranges of $\mathrm{IC}_{50}$ values obtained were 5.7-21.3 and 5.8-37.4 $\mu \mathrm{g} / \mathrm{mL}$ against HCT-116 and MCF-7, respectively; which is 3.8 and 6.5-fold (based on the least $\mathrm{IC}_{50}$ values) more significant relative to the reference chemotherapeutic drug doxorubicin. In HepG-2 cells, the analogue $13 \mathrm{~h}$ exhibited the highest cytotoxicity with $\mathrm{IC}_{50}$ value of $19.2 \mu \mathrm{g} / \mathrm{mL}$ relative to doxorubicin $\left(\mathrm{IC}_{50}=21.6 \mu \mathrm{g} / \mathrm{mL}\right.$ ). The observed cytotoxicity was specific to cancerous cells, as evidenced by the minimal toxicity in the noncancerous control skin-fibroblast cells. ELISA results indicated that the observed antiproliferative effect against examined cancer cell lines is mediated via engaging the activation of apoptosis as illustrated by the significant increase in proapoptotic protein markers (p53, bax and caspase-3) and reduction in the antiapoptotic marker bcl-2. Taken together, results of the present study emphasize the potential of spiro pyrazole-oxindole analogues as valuable candidate anticancer agents against human cancer cells.
\end{abstract}

Keywords: isatin; spiro pyrazole-oxindoles; antiproliferative agents; apoptosis 


\section{Introduction}

Cancer is a primary global burden disease that is classified as the second-leading cause of death after cardiovascular diseases [1,2]. The toxicity of the currently available repertoire of anticancer drugs and the inefficiency of chemotherapies are two major limitations in the battle against cancer. Therefore, designing and discovering effective and selective antitumor agents remains the primary objective in organic medical chemistry known as targeted therapeutic strategies [3]. One of these strategies is apoptosis a.k.a. programmed cell death that is considered an essential mechanism by the body to eliminate unwanted cells $[4,5]$. Therefore, triggering apoptosis in cancer cells will lead to immediate death and thereby increasing the control of cancer proliferation [4,5]. Methodically understanding the mechanism of apoptosis discloses that it is influenced by the expression of caspases, Bcl-2 family proteins, including either antiapoptotic or proapoptotic members [6,7]. Induction of apoptosis is considered as one of the most successful strategies to target cancer [4-7].

Isatin and its derivatives are a promising class of heterocyclic molecules that have diverse biological activities of interest [8]. The most common application of isatins in organic synthesis is primarily focused on the highly reactive C-3 carbonyl group [9]. The vast majority of reactions of the $\mathrm{C}-3$ carbonyl group of isatins are nucleophilic additions or spiroannulation, which transform it into 2-oxindole derivatives [9]. To this end, 2-Oxindoles, particularly those that are spiro-fused to other cyclic frames, have attracted significant research interest in the disciplines of synthetic organic chemistry and medicinal chemistry [10-14]. They represent the core structures in a variety of natural products and drugs, such as isomitraphylline, isocorynoxine, isorhnchophlline, mitraphylline and uncarine [10-14]. Interestingly spirocyclic oxindoles or spiro-oxindoles combined to a rigid heterocyclic ring at $\mathrm{C}-3$ of the oxindole core are the most efficacious class of small molecules. They inhibit cell proliferation, induce apoptosis in cancer cells and lead to tumor growth regression without affecting normal cells [15-17]. For example, it has been documented that oxindole alkaloids derived from the root bark of Uncaria tomentosa plants exhibit apoptosis-mediated cytotoxicity against acute lymphoblastic leukaemia cells [18].

In this context, the objectives of the current study are three-fold: $(i)$ to design and synthesize a novel series of spiro pyrazole-3,3'-oxindole analogues; (ii) to evaluate their antimicrobial, antioxidant and antiproliferative bioactivity against three cancer cell line types (i.e., MCF-7, HCT-116 and HepG-2) and (iii) to determine the underlying mechanism to induce apoptosis in MCF-7 and HCT-116 cancer cells.

\section{Results and Discussion}

\subsection{Chemistry}

A simple and convenient route for the synthesis of $5^{\prime}$-(substituted)-2', $4^{\prime}$-dihydrospiro (indoline-3,3'-pyrazol)-2-ones and quinoline-4-carboxylic acids was summed up in Figure 1. Different aryl methyl ketones, namely 1-(6-substituted-4-methoxybenzofuran-5-yl)-ethan-1-ones 2a-c [19-21], 1-(6-substituted-4,7-dimethoxybenzofuran-5-yl)-ethan-1-ones 3a-c [19-21] and N-substituted-3-indolyl methyl ketones 4a-i [22,23], were prepared as starting materials for this study. Aldol condensation of isatin (1) with each aryl methyl ketones $2 a-c, 3 a-c$ and $4 a-i$ in the presence of a catalytic amount of diethylamine under stirring for approximately 10-15 days at room temperature yielded the resultant aldol products: 3-hydroxy-3-(2-(aryl)-2-oxoethyl) indolin-2-ones 5a-c, 6a-c and 7a-i.

Compounds $5 \mathrm{a}-\mathrm{c}, 6 \mathrm{a}-\mathrm{c}$ and $7 \mathrm{a}-\mathrm{i}$ were also formed when the reaction was carried out in the presence of a few drops of diethylamine under reflux for $\sim 5 \mathrm{~h}$, which gave products identical in all aspects ( $\mathrm{mp}$, admixed $\mathrm{mp}$ ) with no difference in their yields. Acid dehydration of the latter compounds using glacial acetic acid containing few drops of conc. $\mathrm{HCl}$ afforded the corresponding molecular hybrid 3-(2-(aryl)-2-oxo-ethylidene)indolin-2-ones 8a-c, 9a-c and 10a-i, respectively. 


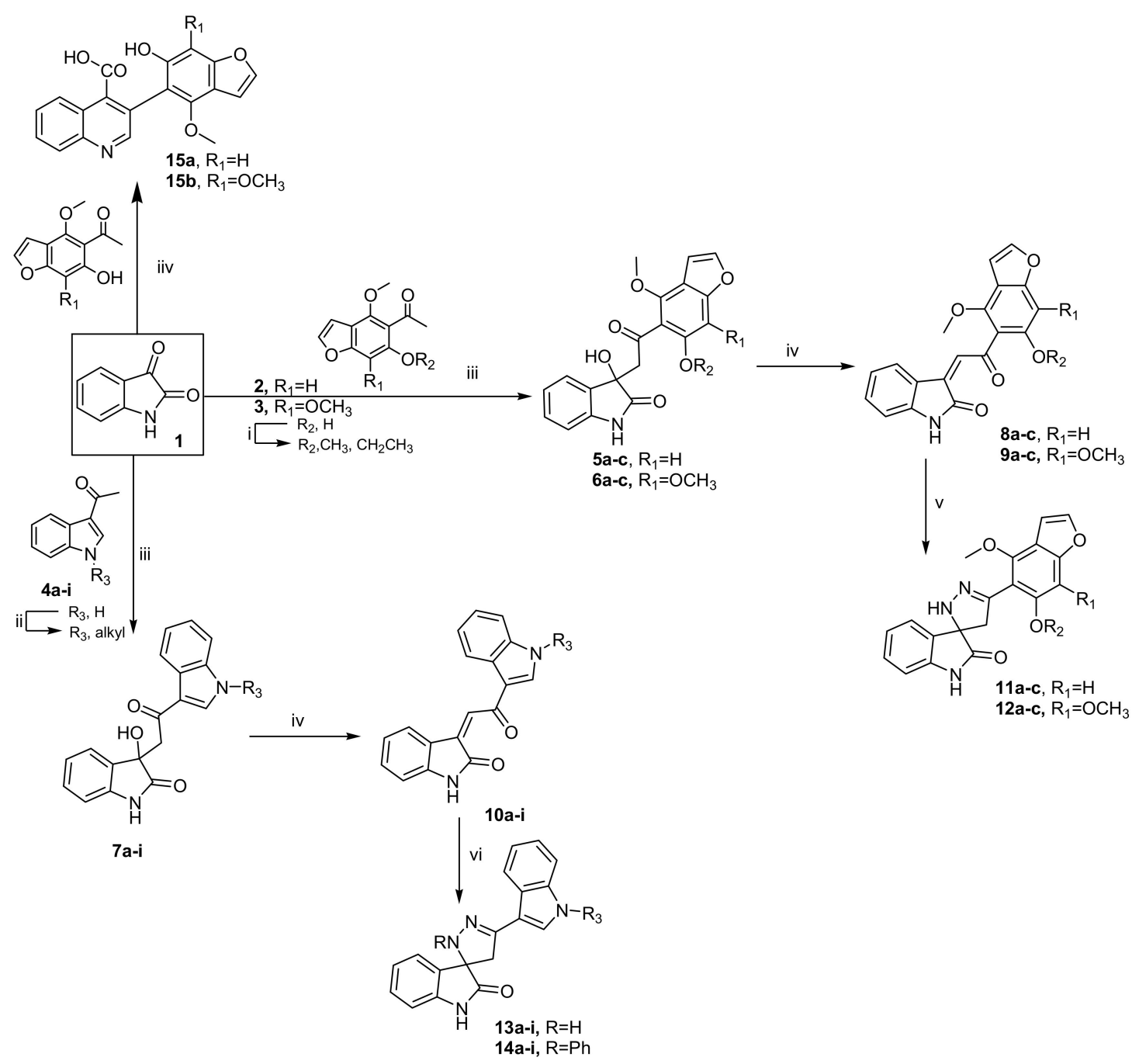

Figure 1. Reagents and conditions: (i) alkyl halide, acetone, $\mathrm{K}_{2} \mathrm{CO}_{3}$, reflux; (ii) alkyl halide, DMSO, $\mathrm{NaOH}$, stirring, r.t.; (iii) EtOH, diethylamine, stirring, r.t. 10-15 days (Method A); EtOH, diethylamine, reflux, 5h (Method B); (iv) gl. AcOH, $\mathrm{HCl}$ (2 drops), $80{ }^{\circ} \mathrm{C}, 30 \mathrm{~min}$; (v) $\mathrm{N}_{2} \mathrm{H}_{4} \cdot \mathrm{H}_{2} \mathrm{O}(98 \%), \mathrm{EtOH}$, gl. $\mathrm{AcOH}$ (2 drops); (vi) $\mathrm{N}_{2} \mathrm{H}_{4} \cdot \mathrm{H}_{2} \mathrm{O}\left(98 \%\right.$ ) or $\mathrm{NH}_{2} \mathrm{NHPh}, \mathrm{EtOH}$, gl.AcOH (2 drops), reflux and (vii) EtOH, $\mathrm{KOH}(33 \%)$, reflux.

Cyclization of compounds $8 \mathrm{a}-\mathrm{c}$ and $9 \mathrm{a}-\mathrm{c}$ upon heating with hydrazine hydrate in dry ethanol and in the presence of a few drops of glacial acetic acid as a catalyst yielded the consequent 2',4'-dihydrospiro(indoline-3,3'-pyrazol)-2-one derivatives 11a-c and 12a-c. Meanwhile, cyclization of 10a-i with hydrazine hydrate and/or phenyl hydrazine based on the above-provided method produced the corresponding $2^{\prime}, 4^{\prime}$-dihydrospiro(indoline-3,3'-pyrazol)-2-ones 13a-i and 2'-phenyl-2', 4'-dihydrospiro(indoline-3,3'-pyrazol)-2-ones 14a-i, respectively.

On the other side, the reaction of isatin (1) with 2a and/or 3a under action of aqueous potassium hydroxide 33\% (Pfitzinger condition [24]) resulted in opening of the 2-oxopyrolidine ring of isatin and then re-cyclized to give 4 -quinoline carboxylic acids $15 \mathrm{a}$ and $15 \mathrm{~b}$, correspondingly. The analytical and spectral data of the entire target compounds were compatible with their structures; see experimental part.

\subsection{Biological Activity}

\subsubsection{Antimicrobial Activity}

The newly synthesized compounds were chosen to be evaluated in vitro towards a variety of pathogenic microorganisms; Gram-positive bacteria: S. aureus (ATCC 6538) and B. subtilis (ATCC 
6633); Gram-negative bacteria: P. areuginosa (ATCC 27853) and E. coli (DSMZ 1058); yeast: C. albicans (ATCC 10231) and S. cerevisiae (ATCC 9080) and fungi: A. niger (NRRL A-326) using the disk diffusion method at a single dose of $20 \mu \mathrm{l}$. The results are shown in Table 1 as the growth inhibition zone $(\mathrm{mm})$. Compounds $13 \mathrm{a}$ and $13 \mathrm{~b}$ exhibited potent activity against $C$. albicans and S. cerevisiae with an inhibition zone of $18,18,20$ and $18 \mathrm{~mm}$ compared to the reference drug amphotericin B of 24.8 and 23.5 $\mathrm{mm}$. Besides, 11a, 11b and 11c showed significant inhibition zones of 20, 18 and $20 \mathrm{~mm}$, respectively, towards C. albicans. Meanwhile, 11c has the most potent activity, with a growth inhibition zone of $25 \mathrm{~mm}$ higher than the reference drug amphotericin B of $23.5 \mathrm{~mm}$ towards C. albicans. On the other hand, compounds $12 \mathrm{a}, 12 \mathrm{~b}, 12 \mathrm{c}$ and 15a resulted in significant growth inhibition zones of 16, 18, 18 and $16 \mathrm{~mm}$, respectively, against $B$. subtilis compared to the reference drug amoxicillin of the growth inhibition zone $28.4 \mathrm{~mm}$. While $12 \mathrm{~b}, 12 \mathrm{c}$ and 15 a revealed significant activity against $P$. areuginosa with growth inhibition zones of 24, 20 and $24 \mathrm{~mm}$, respectively, compared to ciprofloxacin with a zone inhibition value of $30.2 \mathrm{~mm}$ (Table 1). The rest of the tested compounds exhibited trivial or no effects on the pathogenic microorganisms under investigation.

Table 1. Antimicrobial activity of the most active compounds (20 $\mathrm{mg}$ per disc). ${ }^{\mathrm{a}}$.

\begin{tabular}{|c|c|c|c|c|c|c|c|}
\hline \multirow{3}{*}{ Compd. No ${ }^{b}$} & \multicolumn{7}{|c|}{ Inhibition Zone (mm) } \\
\hline & \multicolumn{2}{|c|}{ Gram-Positive } & \multicolumn{2}{|c|}{ Gram-Negative } & \multicolumn{2}{|c|}{ Yeast } & \multirow{2}{*}{$\begin{array}{c}\text { Fungi } \\
\text { A. niger } \\
\text { (NRRL } \\
\text { A-326) }\end{array}$} \\
\hline & $\begin{array}{l}\text { S. aureus } \\
\text { (ATCC } \\
\text { 6538) }\end{array}$ & $\begin{array}{c}\text { B. subtilis } \\
\text { (ATCC } \\
6633 \text { ) }\end{array}$ & $\begin{array}{l}\text { P. aeruginosa } \\
\text { (ATCC 27853) }\end{array}$ & $\begin{array}{c}\text { E. coli } \\
\text { (DSMZ } \\
\text { 1058) }\end{array}$ & $\begin{array}{c}\text { C. albicans } \\
\text { (ATCC 10231) }\end{array}$ & $\begin{array}{l}\text { S. cerevisiae } \\
\text { (ATCC 9080) }\end{array}$ & \\
\hline $11 a$ & - & 12 & 8 & - & 20 & 16 & - \\
\hline $11 b$ & - & 12 & 12 & - & 18 & 18 & - \\
\hline $11 c$ & - & 10 & 10 & - & 20 & 25 & - \\
\hline $12 a$ & 8 & 16 & 18 & - & 12 & 10 & - \\
\hline $12 b$ & 10 & 18 & 24 & - & 10 & 10 & 8 \\
\hline $12 c$ & 10 & 18 & 20 & - & 10 & 10 & - \\
\hline $13 a$ & - & - & - & - & 18 & 20 & - \\
\hline $15 a$ & 8 & 16 & 24 & - & 12 & - & 10 \\
\hline $15 b$ & 8 & 10 & - & - & 8 & - & - \\
\hline Amoxicillin & 25.6 & 28.4 & - & - & - & - & - \\
\hline Ciprofloxacin & - & - & 30.2 & 25.8 & - & - & - \\
\hline Amphotericin B & - & - & - & - & 24.8 & 23.5 & 26.7 \\
\hline
\end{tabular}

${ }^{\mathrm{a}}$ disk diffusion method and ${ }^{\mathrm{b}}$ concentration $20 \mu \mathrm{g}$.

\subsubsection{Antioxidant Activity}

Antioxidant activity of the newly synthesized $13 a-i, 14 a-i, 11 a-c$ and $12 a-c$ were assessed in terms of hydrogen-donating or radical-scavenging ability via the stable free radical 1,1-diphenyl-2-picrylhydrazyl (DPPH) using ascorbic acid as a reference at a concentration of $20 \mu \mathrm{g} / \mathrm{l}$. The results indicate that the ability of the tested compounds to reduce a solution of violet DPPH radical, rendering it colorless, increases after 15 to $60 \mathrm{~min}$. Compounds $13 \mathrm{a}, 13 \mathrm{~b}, 13 \mathrm{~g}, 13 \mathrm{i}, 14 \mathrm{a}, 14 \mathrm{~b}$, $14 \mathrm{~d}$ and $14 \mathrm{i}$ exhibited moderate free radical-scavenging effects after $60 \mathrm{~min}$, ranging from 53.67\% to $69.18 \%$ compared to ascorbic acid of $99.67 \%$. Notably, compounds $12 \mathrm{~h}$ and $12 \mathrm{a}$ revealed potent free radical-scavenging activity after $60 \mathrm{~min}$ that is equivalent to of $85.99 \%$ and $81.41 \%$, respectively, compared to $99.67 \%$ given by a standard solution of ascorbic acid (Table 2 ). 
Table 2. Scavenging activity \% on DPPH radicals of the most active compounds at a concentration of $20 \mu \mathrm{g} / \mathrm{l}$.

\begin{tabular}{|c|c|c|c|c|}
\hline \multirow{2}{*}{ Compd. No } & \multicolumn{4}{|c|}{ Scavenging Activity (\%) ${ }^{a}$ at Different Time (min) } \\
\hline & 15 & 30 & 45 & 60 \\
\hline $11 a$ & $6.86 \pm 1.17$ & $10.26 \pm 1.37$ & $17.73 \pm 1.28$ & $26.87 \pm 1.56$ \\
\hline $11 b$ & $9.60 \pm 1.77$ & $14.28 \pm 1.52$ & $20.44 \pm 1.65$ & $30.76 \pm 2.04$ \\
\hline $11 c$ & $40.65 \pm 1.28$ & $40.65 \pm 1.81$ & $40.65 \pm 1.67$ & $40.65 \pm 1.35$ \\
\hline $12 a$ & $56.43 \pm 1.08$ & $67.09 \pm 1.45$ & $76.92 \pm 1.51$ & $81.41 \pm 1.37$ \\
\hline $12 b$ & $17.29 \pm 1.53$ & $23.46 \pm 1.64$ & $30.56 \pm 1.49$ & $40.65 \pm 1.46$ \\
\hline $12 c$ & $9.76 \pm 1.76$ & $10.24 \pm 1.26$ & $11.39 \pm 1.53$ & $13.97 \pm 1.55$ \\
\hline $13 a$ & $41.14 \pm 1.25$ & $45.77 \pm 1.36$ & $56.55 \pm 1.99$ & $64.08 \pm 2.01$ \\
\hline $13 b$ & $43.52 \pm 1.98$ & $47.05 \pm 1.81$ & $56.33 \pm 1.29$ & $65.55 \pm 1.55$ \\
\hline $13 c$ & $13.97 \pm 1.36$ & $20.97 \pm 1.26$ & $23.96 \pm 1.51$ & $35.13 \pm 1.61$ \\
\hline $13 d$ & $19.32 \pm 1.24$ & $31.32 \pm 1.81$ & $25.92 \pm 1.24$ & $39.70 \pm 1.99$ \\
\hline $13 e$ & $9.10 \pm 1.38$ & $26.15 \pm 1.26$ & $36.70 \pm 1.62$ & $48.13 \pm 1.82$ \\
\hline $13 f$ & $17.90 \pm 1.62$ & $28.28 \pm 1.61$ & $34.28 \pm 1.27$ & $40.74 \pm 1.54$ \\
\hline $13 g$ & $25.95 \pm 1.85$ & $44.00 \pm 1.46$ & $49.25 \pm 1.77$ & $53.67 \pm 1.81$ \\
\hline $13 \mathrm{~h}$ & $15.22 \pm 1.98$ & $16.31 \pm 1.96$ & $20.58 \pm 1.48$ & $35.71 \pm 1.91$ \\
\hline $14 \mathrm{i}$ & $45.88 \pm 1.05$ & $54.32 \pm 1.08$ & $60.60 \pm 1.64$ & $69.18 \pm 1.65$ \\
\hline $14 a$ & $41.09 \pm 2.05$ & $51.52 \pm 1.91$ & $53.98 \pm 2.06$ & $59.22 \pm 2.14$ \\
\hline $14 b$ & $42.36 \pm 1.45$ & $58.08 \pm 1.28$ & $60.27 \pm 1.66$ & $65.96 \pm 1.64$ \\
\hline $14 c$ & $14.85 \pm 1.36$ & $22.56 \pm 1.79$ & $26.29 \pm 1.23$ & $39.48 \pm 1.61$ \\
\hline $14 d$ & $39.91 \pm 1.75$ & $41.82 \pm 1.49$ & $44.96 \pm 1.37$ & $55.44 \pm 1.33$ \\
\hline $14 \mathrm{e}$ & $17.89 \pm 1.23$ & $28.18 \pm 1.27$ & $30.87 \pm 1.98$ & $34.89 \pm 1.72$ \\
\hline $14 \mathrm{f}$ & $9.05 \pm 1.63$ & $10.15 \pm 1.83$ & $16.19 \pm 1.21$ & $22.93 \pm 1.62$ \\
\hline $14 \mathrm{~g}$ & $8.39 \pm 1.14$ & $11.87 \pm 1.23$ & $14.08 \pm 2.01$ & $26.55 \pm 2.13$ \\
\hline $14 \mathrm{~h}$ & $57.93 \pm 1.36$ & $67.35 \pm 1.35$ & $72.00 \pm 1.82$ & $85.99 \pm 2.17$ \\
\hline $14 \mathrm{i}$ & $39.91 \pm 1.87$ & $41.82 \pm 1.09$ & $44.96 \pm 1.66$ & $55.44 \pm 1.55$ \\
\hline $15 a$ & $9.36 \pm 1.25$ & $14.15 \pm 1.61$ & $20.39 \pm 1.92$ & $24.77 \pm 2.05$ \\
\hline $15 b$ & $23.60 \pm 1.36$ & $32.73 \pm 1.13$ & $39.23 \pm 1.29$ & 47.48 \\
\hline Negative control & 0 & 0 & 0 & 0 \\
\hline Ascorbic acid & $94.37 \pm 1.74$ & $97.45 \pm 1.32$ & $98.78 \pm 0.94$ & $99.67 \pm 0.28$ \\
\hline
\end{tabular}

${ }^{a}$ Results are the mean of three independent experiments. Data $=$ mean \pm SD.

\subsubsection{Evaluation of In Vitro Anti-Proliferative Activity}

The newly synthesized compounds $11 \mathrm{a}-\mathrm{c}, 12 \mathrm{a}-\mathrm{c}, 13 \mathrm{a}-\mathrm{i}$ and $14 \mathrm{a}-\mathrm{i}$ were screened for their antiproliferative activity against human breast cancer (MCF-7), human colon cancer (HCT-116) and human liver cancer (HepG2), as well as the normal skin fibroblast cell (BJ-1) through in vitro MTT assay (Table 3). The obtained results indicated that all congeners under investigation exhibited selective cytotoxicity against HCT-116 and MCF-7 cell lines as compared to the reference doxorubicin, with antiproliferative activity ranging from $84.6 \%$ to $97.9 \%$. Minimal cytotoxicity was observed against normal skin fibroblast cells (BJ-1). With reference to MCF-7 cells, all compounds showed potent antiproliferative activity ranging from $79.8 \%$ to $97.4 \%$, as compared to the positive control drug doxorubicin, except compounds 14i, 11c and 12c, which exhibited low antiproliferative activity within the range of $52.3 \%-0 \%$. Regarding the HepG-2 cancer cell line, only compounds 13a-i have been investigated, showing potent antiproliferative activity ranging from $72.8 \%$ to $96.8 \%$. Interestingly, most of the tested analogues revealed minimal inhibition effects ranging from $16.6 \%$ to $5.0 \%$ against normal skin fibroblast cells (BJ-1), with the exception of compound 13i (69.4\%). This finding encouraged the belief that these compounds possess high selectivity against cancer cells and high safety margins against normal cells, thereby highlighting their utilities as potent and safe anticancer drugs for further studies. 
Table 3. Antiproliferative activity of the newly synthesized compounds against human carcinoma cell lines and normal skin fibroblast cells (BJ-1) at $100 \mu \mathrm{g} / \mathrm{ml}$.

\begin{tabular}{cccccccccc}
\hline \multirow{2}{*}{$\begin{array}{c}\text { Compd. } \\
\text { No. }\end{array}$} & \multicolumn{3}{c}{ Growth Inhibition (\%) } & \multicolumn{5}{c}{ Growth Inhibition (\%) } \\
\cline { 2 - 9 } & HCT-116 & HepG-2 & MCF-7 & BJ-1 & $\begin{array}{c}\text { Compd. } \\
\text { No. }\end{array}$ & HCT-116 & HepG-2 & MCF-7 & BJ-1 \\
\hline $\mathbf{1 1 a}$ & 96.2 & - & 94.3 & 6.2 & $\mathbf{1 3 g}$ & 92.4 & 81.9 & 91.6 & 13.0 \\
$\mathbf{1 1 b}$ & 94.9 & - & 92.3 & 10.1 & $\mathbf{1 3 h}$ & 91.3 & 79.5 & 93.4 & 14.1 \\
$\mathbf{1 1 c}$ & 30.2 & - & 0 & 45.2 & $\mathbf{1 3 i}$ & 97.7 & 96.8 & 97.8 & 69.4 \\
$\mathbf{1 2 a}$ & 96.7 & - & 93.6 & 9.1 & $\mathbf{1 4 a}$ & 91.2 & - & 90.4 & 14.2 \\
$\mathbf{1 2 b}$ & 95.1 & - & 97.4 & 5.0 & $\mathbf{1 4 b}$ & 84.6 & - & 80.3 & 8.1 \\
$\mathbf{1 2 c}$ & 12.4 & - & 6.3 & 62.3 & $\mathbf{1 4 c}$ & 91.8 & - & 92.3 & 13.6 \\
$\mathbf{1 3 a}$ & 96.9 & 89.3 & 96.4 & 11.6 & $\mathbf{1 4 d}$ & 96.2 & - & 94 & 9.5 \\
$\mathbf{1 3 b}$ & 94.5 & 81.4 & 95.4 & 10.4 & $\mathbf{1 4 e}$ & 35.1 & - & 85.3 & 16.6 \\
$\mathbf{1 3 c}$ & 97.9 & 90.9 & 97.8 & 5.1 & $\mathbf{1 4 f}$ & 91.4 & - & 89.3 & 14.5 \\
$\mathbf{1 3 d}$ & 94.6 & 82.7 & 96.4 & 7.0 & $\mathbf{1 4 g}$ & 92.1 & - & 90.6 & 16.0 \\
$\mathbf{1 3 e}$ & 90.4 & 79.8 & 96.4 & 10.3 & $\mathbf{1 4 h}$ & 96.2 & - & 94 & 86.5 \\
$\mathbf{1 3 f}$ & 86.5 & 72.8 & 79.7 & 16.4 & $\mathbf{1 4 i}$ & 35.1 & - & 52.3 & 78.6 \\
Doxorubicin & 100 & 100 & 96.8 & 0 & & 100 & 100 & 96.8 & 0 \\
\hline
\end{tabular}

The dose-response cytotoxicity curves for selected drugs with potent antiproliferative activity (i.e., 11a and 13h) with reference to the BJ-1 line, are depicted in Figure 2.

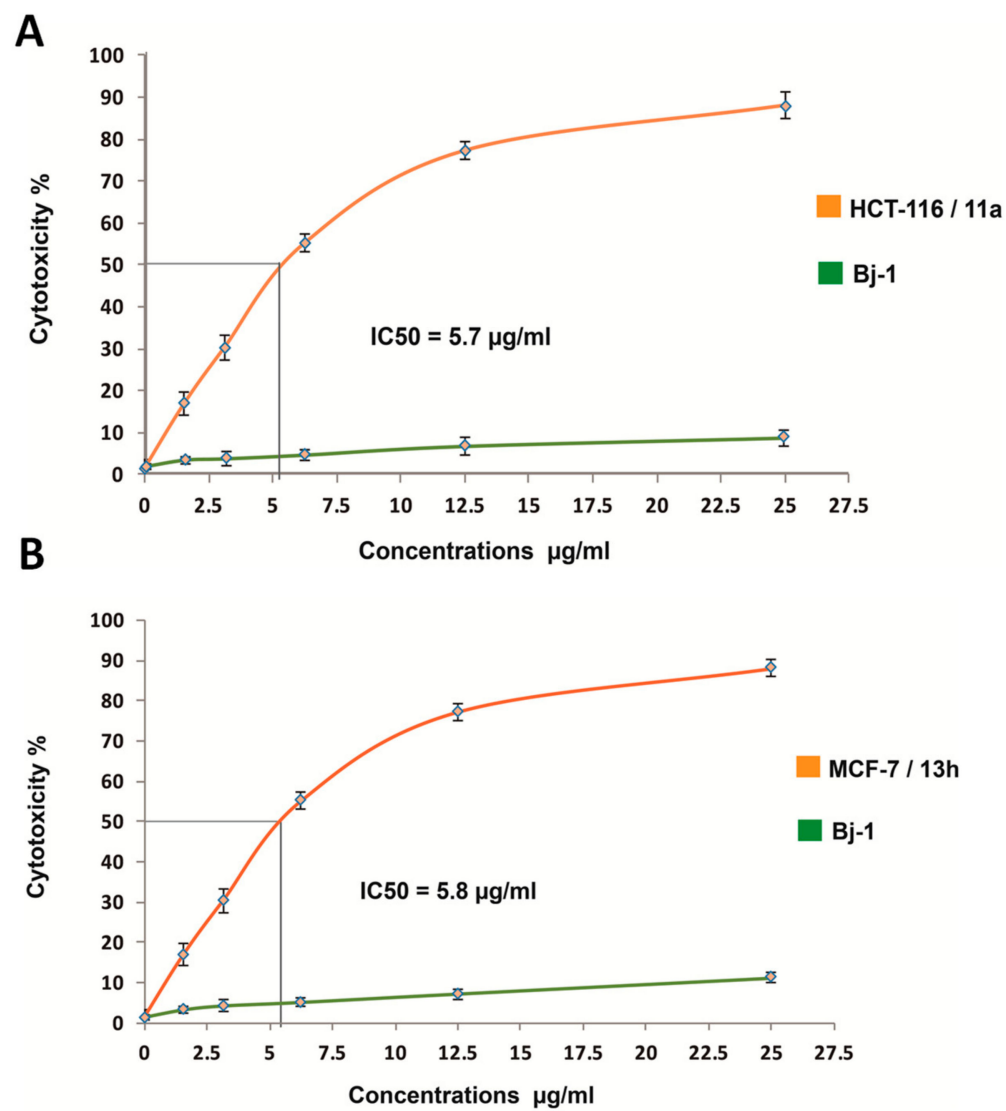

Figure 2. Cytotoxicity (\%) dose-response curves of increasing concentrations for selected synthesized spiro pyrazole-oxindole congeners against cancerous cells. (A) Dose-response curve of 11a congener against HCT-116 as compared to BJ-1. (B) (A) Dose-response curve of 13 h congener against MCF-7 as compared to BJ-1. IC50 values in $\mu \mathrm{g} / \mathrm{mL}$ were calculated by probit analysis using an Excel-based macro.

The concentration required for $50 \%$ inhibition of cell viability $\left(\mathrm{IC}_{50}\right)$ has been calculated for the most active compounds that exhibited low toxicity against BJ-1 cells using doxorubicin as a reference drug (Table 4). Interestingly, the $\mathrm{IC}_{50}$ values of compounds $11 \mathrm{a}, 11 \mathrm{~b}, 12 \mathrm{a}, 12 \mathrm{~b}, 13 \mathrm{~b}, 13 \mathrm{c}$ and $13 \mathrm{~h}$ were 
shown to be evidently more potent than the reference doxorubicin of $\mathrm{IC}_{50}=21.6 \mu \mathrm{g} / \mathrm{mL}$ against the HCT-116 cancer cell line. Their activity were in the descending order of 11a $>12 a>12 b>13 c>11 b>$ $13 \mathrm{~h}>13 \mathrm{~b}$ with $\mathrm{IC}_{50}$ of 5.7, 5.8, 7.9, 14.7, 16.4, 20.5 and $21.3 \mu \mathrm{g} / \mathrm{mL}$, respectively. Moreover, data revealed that compound $13 \mathrm{~h}$ induced the highest cytotoxicity against the HepG-2 cancer cell line, with $\mathrm{IC}_{50}$ of $19.2 \mu \mathrm{g} / \mathrm{mL}$ as compared to the reference doxorubicin with $\mathrm{IC}_{50}$ of $21.6 \mu \mathrm{g} / \mathrm{mL}$. On the other hand, most of the tested compounds were found to exhibit potent cytotoxicity with $\mathrm{IC}_{50}$, values ranging from 5.8 to $37.4 \mathrm{ug} / \mathrm{mL}$ towards the MCF-7 cancer cell line relative to the reference doxorubicin with $\mathrm{IC}_{50}$ of $37.6 \mu \mathrm{g} / \mathrm{mL}$. The most potent drugs were $13 \mathrm{~h}$ and $12 \mathrm{~b}$, with exhibited $\mathrm{IC}_{50}$ values of 5.8 and $16.7 \mu \mathrm{g} / \mathrm{mL}$, respectively.

Table 4. $\mathrm{IC}_{50}$ values of spiro pyrazole-oxindole congeners against human cancer cell lines.

\begin{tabular}{|c|c|c|c|}
\hline \multirow{2}{*}{ Compd. No. } & \multicolumn{3}{|c|}{$\mathrm{IC}_{50} \mathrm{ug} / \mathrm{ml}$} \\
\hline & НСТ-116 & HepG-2 & MCF-7 \\
\hline $11 a$ & 5.7 & - & 21.1 \\
\hline $11 b$ & 16.4 & - & 19.4 \\
\hline $12 a$ & 5.8 & - & 20.2 \\
\hline $12 b$ & 7.9 & - & 16.7 \\
\hline $13 a$ & 31.3 & 60.6 & 32.4 \\
\hline $13 b$ & 21.3 & 48.0 & 24.0 \\
\hline $13 c$ & 14.7 & 27.0 & 24.1 \\
\hline $13 d$ & 26.9 & 60.9 & 25.4 \\
\hline $13 e$ & 35.4 & 67.1 & 31.9 \\
\hline $13 f$ & 28.4 & 83.6 & 32.1 \\
\hline $13 \mathrm{~g}$ & 35.3 & 72.2 & 43.0 \\
\hline $13 \mathrm{~h}$ & 20.5 & 19.2 & 5.8 \\
\hline $14 a$ & 36.2 & - & 32.3 \\
\hline $14 \mathrm{~b}$ & 40.1 & - & 36.3 \\
\hline $14 c$ & 40.5 & - & 32.5 \\
\hline 14d & 30.7 & - & 31.6 \\
\hline $14 \mathrm{e}$ & - & - & 54.0 \\
\hline $14 \mathrm{f}$ & 35.8 & - & 31.2 \\
\hline $14 \mathrm{~g}$ & 38.0 & - & 37.4 \\
\hline Doxorubicin & 26.1 & 21.6 & 37.6 \\
\hline
\end{tabular}

All $\mathrm{IC}_{50}$ values were calculated for the timepoint $48 \mathrm{~h}$ post-treatment.

\subsubsection{Apoptosis Induction in MCF-7and HCT-116 Cancer Cells}

The promising antiproliferative results reported for compounds 11a, 11b, 12a, 12b and 13c against cell lines under study have prompted us to investigate the mechanism of cell death induced by these compounds. Apoptosis induction was examined in both MCF-7 and HCT-116 cancer cells by assaying the level of its key protein markers, namely: proapoptotic (p53, Bcl 2-associated X, Bax and caspases3) and antiapoptotic (B-cell lymphoma-2, Bcl-2). MCF-7 and HCT-116 cells undergoing apoptosis was detected by use of the ELISA technique. Protein marker levels were quantified according to Bradford assay. The results indicated that compounds $11 \mathrm{a}, 11 \mathrm{~b}, 12 \mathrm{a}$ and $12 \mathrm{~b}$ significantly reduced the expression levels of the antiapoptotic protein Bcl-2 by 50\%, 63\%, 52\% and 51\%, respectively, towards MCF-7 cells compared to the control (Table 5). Meanwhile, treatment of the HCT-116 cells with compounds $11 \mathrm{a}, 11 \mathrm{~b}, 12 \mathrm{a}$ and $12 \mathrm{~b}$ conspicuously reduced the expression levels of the antiapoptotic protein Bcl-2 by $\sim 66 \%, 76 \%, 26 \%$, and $29 \%$, respectively, compared to the control (Table 6 ). 
Table 5. Effect of analogues 11a, 11b, 12a, 12b and 13c on cleaved caspase-3 levels, and expression levels of Bcl-2 and Bax in MCF-7 cancer cells treated with the compounds at their $\mathrm{IC}_{50}$ concentrations.

\begin{tabular}{ccccc}
\hline Compounds & $\begin{array}{c}\text { Caspase-3 Activity } \\
\text { \% }\end{array}$ & $\begin{array}{c}\text { Bcl-2 (ng/50 } \mathbf{~ m g} \\
\text { Protein) }\end{array}$ & $\begin{array}{c}\text { p53 (Pg/50 mg } \\
\text { Protein) }\end{array}$ & $\begin{array}{c}\text { Bax (pg/50 mg } \\
\text { Protein) }\end{array}$ \\
\hline Control (MCF-7) & $10.2 \pm 2.84$ & $25.13 \pm 3.45$ & $4.18 \pm 0.58$ & $39.56 \pm 4.56$ \\
11a & $16.67 \pm 0.67$ & $12.3 \pm 2.26$ & $14.45 \pm 0.82$ & $122.34 \pm 3.45$ \\
11b & $16.19 \pm 0.79$ & $16.18 \pm 0.78$ & $5.85 \pm 0.75$ & $109.35 \pm 4.05$ \\
12a & $14.18 \pm 0.74$ & $13.09 \pm 2.27$ & $13.31 \pm 1.08$ & $113.09 \pm 1.98$ \\
12b & $47.25 \pm 1.89$ & $12.87 \pm 1.84$ & $29.58 \pm 2.53$ & $167.07 \pm 4.83$ \\
13c & $39.07 \pm 4.97$ & $44.5 \pm 4.56$ & $7.34 \pm 1.5$ & $88.34 \pm 3.79$ \\
\hline
\end{tabular}

Data $=$ mean \pm SD.

Table 6. Effect of compounds 11a, 11b, 12a, 12b and 13c on active caspase-3 levels, and expression levels of Bcl-2 and Bax in HCT-116 cancer cells treated with the compounds at their $\mathrm{IC}_{50}$ concentrations.

\begin{tabular}{ccccc}
\hline Compounds & $\begin{array}{c}\text { Caspase-3 Activity } \\
\text { \% }\end{array}$ & $\begin{array}{c}\text { Bcl-2 (ng/50 } \mathbf{~ m g} \\
\text { Protein) }\end{array}$ & $\begin{array}{c}\text { p53 (pg/50 } \mathbf{~ m g} \\
\text { Protein) }\end{array}$ & $\begin{array}{c}\text { Bax (pg/50 } \mathbf{~ m g ~} \\
\text { Protein) }\end{array}$ \\
\hline Control (HCT-116) & $13.60 \pm 2.45$ & $23.56 \pm 3.56$ & $1.68 \pm 0.06$ & $118.54 \pm 0.83$ \\
$\mathbf{1 1 a}$ & $19.12 \pm 0.89$ & $8.2 \pm 1.26$ & $16.2 \pm 0.56$ & $159.26 \pm 0.96$ \\
$\mathbf{1 1 b}$ & $14.04 \pm 0.54$ & $7.25 \pm 1.45$ & $3.25 \pm 0.15$ & $119.14 \pm 1.65$ \\
$\mathbf{1 2 a}$ & $17.43 \pm 0.58$ & $21.13 \pm 1.45$ & $23.11 \pm 1.22$ & $124.56 \pm 0.95$ \\
$\mathbf{1 2 b}$ & $33.12 \pm 1.37$ & $18.87 \pm 1.84$ & $48.07 \pm 1.94$ & $191.07 \pm 1.95$ \\
$\mathbf{1 3 c}$ & $47.32 \pm 6.32$ & $57.45 \pm 6.45$ & $2.34 \pm 0.95$ & $123.45 \pm 7.45$ \\
\hline
\end{tabular}

Data $=$ mean \pm SD

\subsubsection{Effect of the Newly Synthesized Compounds on Key Pro- and Antiapoptotic Markers}

Cell apoptosis is a sophisticated meticulously regulated biological process that is associated with complex signaling pathway responses $[7,25]$. Caspases are a group of cysteine-aspartic acid proteases that play a pivotal role as in the execution and intracellular regulation of apoptosis [26]. Caspase- 3 is a key executioner of apoptosis that is activated both extrinsically (death ligands) and intrinsically (mitochondrial dysfunction) $[27,28]$. On the other hand, the tumor suppressor protein p53 is a positive regulator of the Bcl-2-associated X (Bax), Bcl-2-associated death promoter (Bad) and Bcl-2 homologous antagonist/killer (Bak) proapoptotic proteins to prevent Bcl-2 capture [7,29]. Free Bax, Bad and Bak subsequently bind to the mitochondrial membrane to induce mitochondrial damage and cell apoptosis [30]. Zhang and his coworker have demonstrated that p53 promotes the transcription of Bax and Bak, which regulate the release of cytochrome $\mathrm{c}$ from the mitochondria and result in cell apoptosis by activating the cleaving of caspase-3 [7]. Therefore, the increase in the expression of P53 and Bax causes the increase of the protein expression levels of active caspase- 3 . In the present study, treatment of the MCF-7 cell with compounds $11 \mathrm{a}, 11 \mathrm{~b}, 12 \mathrm{a}, 12 \mathrm{~b}$ and $13 \mathrm{c}$ resulted in a significant elevation of active caspase-3 protein levels by $~ 1.6,1.6,1.4,4.6$ and 3.8 folds, respectively, compared to the control. In line with the previous, compounds 11a, 11b, 12a, 12b and 13c increased the expression levels of proapoptotic p53 and Bax compared to the control. In addition, treatment of the HCT-116 cell with compounds 11a, 11b, 12a, 12b and 13c gave rise of caspase-3 protein levels by $\sim 1.5,1.0,1.3$ and 2.4 folds, respectively, compared to the control, as well as increase the expressions of proapoptotic proteins p53 and Bax compared to the control. Despite that the compound 13c increased the expression of active caspase-3, p53 and Bax proteins, it caused an increase of the Bcl-2 protein level. This result suggests that, additional yet undefined regulatory mechanism might be present to fine-tune apoptosis induction by 13 c treatment (Table 5), which merits further investigation.

In this context, an evident correlation between the magnitude of elevation in the Bax/Bcl-2 ratio that is proportional to that of caspase-3 upregulation was found. This correlation is regarded as a key signal that triggers the execution of apoptosis in pyrazole-3,3'-oxindole-treated cancer cells, thereby leading to the observed potent antiproliferative activity in an MTT assay. 
In conclusion, the present work highlights the potential application of a novel series of spiro pyrazole-3,3'-oxindoles as powerful synthetic antiproliferative agents acting via the induction of apoptosis in MCF7 and HCT-116 cancer cell lines. Further thorough investigation is warranted in order to fully explore the spectrum of cytotoxicity of these novel spiro pyrazole-3,3'-oxindole analogues against a battery of cancerous cells lines, as well as their in vivo biological activity in experimental animal models.

\section{Materials and Methods}

\subsection{Chemicals and Supplies}

Unless otherwise stated, all chemicals, including MTT (3-[4,5-dimethylthiazol-2yl]-2.5diphenylterazolium bromide) were purchased from Sigma Aldrich (St Louis, MO, USA). RPM1 1640, FBS, 1-glutamine and penicillin/streptomycin were obtained from Hyclone Laboratories (Logan, UT, USA).

\subsection{Chemical and Physical Characterization of Synthesized Spiro Pyrazole-Oxindole Congeners}

All reagents and solvents were of analytical grade. Melting points were determined on the digital melting point apparatus (Electro thermal 9100, Electro thermal Engineering Ltd. serial No. 8694, Rochford, United Kingdom) and are uncorrected. The reaction progress was monitored by thin-layer chromatography (TLC) using silica gel plates (POLYGRAM SILG/UV254, $0.20 \mathrm{~mm}$ ), which were visualized under UV light 254 and $365 \mathrm{~nm}$. Elemental analyses were carried out on a Perkin-Elmer 2400 analyzer (Perkin-Elmer, PerkinElmer, Inc, Waltham, MA, United States) and were found within $\pm 0.4 \%$ of the theoretical values. IR spectra were implemented on a Beckman infrared spectrophotometer PU 7712 using a $\mathrm{KBr}$ disk. ${ }^{1} \mathrm{H}$ and ${ }^{13} \mathrm{C}$ NMR spectra were measured with a Bruker Advance spectrometer (Bruker, Germany) at 400 and $100 \mathrm{MHz}$, respectively, using TMS as the internal standard. Chemical shifts were represented as parts per million ( $\mathrm{ppm}$ ) relative to the solvent peak. Mass spectra (EI) were recorded on Jeol JMS-AX 500 (EI) 70ev (JEOL Ltd. 1-2, Musashino 3-chome Akishima, Tokyo 196-8558, Japan).

\subsection{Synthesis}

3.3.1. General Procedure for the Preparation of 3-hydroxy-3-(2-(aryl)-2-oxoethyl)indolin-2-ones 5a-c, 6a-c and $7 \mathbf{a}-\mathbf{i}$

Method A: To a solution of isatin (1) (10 mmol) and aryl methyl ketone $\mathbf{2 a}-\mathbf{c}, \mathbf{3 a}-\mathbf{c}$ and $\mathbf{4 a}-\mathbf{i}$ $(10 \mathrm{mmol})$ in absolute ethanol $(20 \mathrm{~mL})$, diethylamine $(10 \mathrm{mmol})$ was added. The reaction mixture was stirred at room temperature for approximately 10-15 days. The solid formed was filtered off, washed with water, air-dried and used in the next step without further purification. In the case of compounds $\mathbf{5 a}, \mathbf{6 a}$ and $\mathbf{7 a}$, the product was obtained only after stirring for $5 \mathrm{~h}$ at room temperature and left overnight.

Method B: A solution of isatin (1) (10 mmol) and aryl methyl ketone $\mathbf{2 a}-\mathbf{c}, \mathbf{3 a}-\mathbf{c}$ and $\mathbf{4 a}-\mathbf{i}(10 \mathrm{mmol})$ in absolute ethanol $(20 \mathrm{~mL})$ containing diethylamine $(10 \mathrm{mmol})$ was heated under reflux for $\sim 5 \mathrm{~h}$. The progress of the reaction was monitored using TLC. After the reaction accomplished, the reaction mixture was cooled, and the solid that formed was filtered off, washed with water, air-dried and used in the next step without further purification.

3.3.2. General Procedure for the Preparation of 3-(2-(aryl)-2-oxo-ethylidene)indolin-2-ones 8a-c, 9a-c and $10 \mathbf{a}-\mathbf{i}$

A solution of compound $\mathbf{5 a}-\mathbf{c}, \mathbf{6} \mathbf{a}-\mathbf{c}$ and $\mathbf{7 a}-\mathbf{i}$ in a mixture of glacial acetic acid $(5 \mathrm{~mL})$ and two drops of concentrated $\mathrm{HCl}$ was heated at $80^{\circ} \mathrm{C}$ for $30 \mathrm{~min}$. After cooling, the reaction mixture was quenched in ice-water. The solid that formed was filtered off, washed with water, air-dried and crystallized from ethyl acetate-cyclohexane. 
3-(2-(6-Hydroxy-4-methoxy-benzofuran-5-yl)-2-oxo-ethylidene)indolin-2-one (8a): Yield 54\%; orange powder; $\mathrm{mp} 173-5^{\circ} \mathrm{C}$; IR (KBr, cm $\left.{ }^{-1}\right)$ : $3421(\mathrm{OH}), 3176(\mathrm{NH}), 1705,1685(\mathrm{C}=\mathrm{O}), 1545(\mathrm{C}=\mathrm{C}), 1132,1043$ (C-O-C); ${ }^{1} \mathrm{H}$ NMR $\left(300 \mathrm{MHz}\right.$, DMSO- $\left.d_{6}\right) \delta: 11.77(\mathrm{~s}, 1 \mathrm{H}, \mathrm{OH}), 10.27(\mathrm{~s}, 1 \mathrm{H}, \mathrm{NH}), 7.82(\mathrm{~d}, 1 \mathrm{H}, \mathrm{H}-2$ furan), $7.22(\mathrm{~d}$, 1H, Ar-H), 7.20 (m, 2H, Ar-H), 6.85-6.80 (m, 2H, Ar-H), 6.72 (s, 1H, CH), 6.63 (s, 1H, CH), 4.13 (s, 3H, $\left.\mathrm{OCH}_{3}\right) ;{ }^{13} \mathrm{C}$ NMR $\left(75 \mathrm{MHz}\right.$, DMSO- $\left.d_{6}\right) \delta: 192.71,180.53,161.19,156.93,155.94,152.03,146.82,143.96$, 130.04, 128.72, 127.16, 112.18,110.30, 105.91, 93.85, 62.65; EI-MS: $\mathrm{m} / \mathrm{z}(\%)$ : 335 (M $\left.{ }^{+}, 15\right)$; Anal Calcd for $\mathrm{C}_{19} \mathrm{H}_{13} \mathrm{NO}_{5}$ (335.31): C, 68.06; $\mathrm{H}, 3.91 ; \mathrm{N}, 4.18$; found: $\mathrm{C}, 67.91 ; \mathrm{H}, 3.61 ; \mathrm{N}, 4.01$.

3-(2-(4,6-Dimethoxy-benzofuran-5-yl)-2-oxo-ethylidene)indolin-2-one (8b): Yield 33\%; reddish-brown powder; mp 97-2 ${ }^{\circ} \mathrm{C}$; IR $\left(\mathrm{KBr}, \mathrm{cm}^{-1}\right): 3220(\mathrm{NH}), 1702,1695(\mathrm{C}=\mathrm{O}), 1565(\mathrm{C}=\mathrm{C}), 1138,1086(\mathrm{C}-\mathrm{O}-\mathrm{C}) ;{ }^{1} \mathrm{H}$ NMR (300 MHz, DMSO- $\left.d_{6}\right) \delta: 10.03$ (s, 1H, NH), 7.92 (d, 1H, H-2 furan), 7.56 (d, 1H, Ar-H), 7.25-6.88 $(\mathrm{m}, 6 \mathrm{H}, \mathrm{Ar}-\mathrm{H}), 3.83\left(\mathrm{~s}, 3 \mathrm{H}, \mathrm{OCH}_{3}\right), 3.77\left(\mathrm{~s}, 3 \mathrm{H}, \mathrm{OCH}_{3}\right)$; Anal Calcd for $\mathrm{C}_{20} \mathrm{H}_{15} \mathrm{NO}_{5}$ (349.34): $\mathrm{C}, 68.76 ; \mathrm{H}$, 4.33; N, 4.01; found: $\mathrm{C}, 68.55 ; \mathrm{H}, 4.21 ; \mathrm{N}, 3.95$.

3-(2-(6-Ethoxy-4-methoxy-benzofuran-5-yl)-2-oxo-ethylidene)indolin-2-one (8c): Yield 35\%; reddish-brown powder; $\mathrm{mp} 88-90^{\circ} \mathrm{C}$; IR $\left(\mathrm{KBr}, \mathrm{cm}^{-1}\right)$ : $3210(\mathrm{NH}), 1697,1687(\mathrm{C}=\mathrm{O}), 1555(\mathrm{C}=\mathrm{C}), 1135,1051$ (C-O-C); ${ }^{1} \mathrm{H}$ NMR (300 MHz, DMSO- $\left.d_{6}\right) \delta: 8.19$ (s, $\left.1 \mathrm{H}, \mathrm{NH}\right), 7.97$ (d, 1H, H-2 furan), 7.35-7.10 (m,6H, Ar-H), $6.99(\mathrm{~d}, 1 \mathrm{H}), 5.19\left(\mathrm{q}, 2 \mathrm{H}, \mathrm{CH}_{2}\right), 4.03\left(\mathrm{t}, 3 \mathrm{H}, \mathrm{CH}_{3}\right), 3.77\left(\mathrm{~s}, 3 \mathrm{H}, \mathrm{OCH}_{3}\right) ;{ }^{13} \mathrm{C}$ NMR $\left(75 \mathrm{MHz}, \mathrm{DMSO}-d_{6}\right) \delta$ : 192.07, 180.23, 160.09, 156.71, 155.11, 150.93, 144.52, 140.06, 133.21, 129.11, 127.82, 112.06, 111.13, 150.62, 105.33, 92.57, 64.32, 62.00, 25.35; EI-MS: $m / z(\%): 363\left(\mathrm{M}^{+}, 29\right)$; Anal Calcd for $\mathrm{C}_{21} \mathrm{H}_{17} \mathrm{NO}_{5}$ (363.11): C, $69.41 ; \mathrm{H}, 4.72 ; \mathrm{N}, 3.85$; found: $\mathrm{C}, 69.14 ; \mathrm{H}, 4.50 ; \mathrm{N}, 3.62$.

3-(2-(6-Hydroxy-4,7-dimethoxy-benzofuran-5-yl)-2-oxo-ethylidene)indolin-2-one (9a): Yield 35\%; purple powder; mp 138-5 ${ }^{\circ} \mathrm{C}$; IR (KBr, cm $\left.{ }^{-1}\right)$ : $3421(\mathrm{OH}), 3201(\mathrm{NH}), 1707,1695(\mathrm{C}=\mathrm{O}), 1555(\mathrm{C}=\mathrm{C}), 1119,1053$ (C-O-C); ${ }^{1} \mathrm{H}$ NMR $\left(300 \mathrm{MHz}\right.$, DMSO- $\left.d_{6}\right) \delta: 12.35(\mathrm{~s}, 1 \mathrm{H}, \mathrm{OH}), 10.72(\mathrm{~s}, 1 \mathrm{H}, \mathrm{NH}), 8.42(\mathrm{~d}, 1 \mathrm{H}, \mathrm{H}-2$ furan), $8.07(\mathrm{~d}, 2 \mathrm{H}, \mathrm{Ar}-\mathrm{H}), 7.66-7.58(\mathrm{~m}, 3 \mathrm{H}, \mathrm{Ar}-\mathrm{H}), 7.16(\mathrm{~s}, 1 \mathrm{H}, \mathrm{CH}), 3.96\left(\mathrm{~s}, 3 \mathrm{H}, \mathrm{OCH}_{3}\right), 3.79\left(\mathrm{~s}, 3 \mathrm{H}, \mathrm{OCH}_{3}\right)$; ${ }^{13} \mathrm{C}$ NMR (75 MHz, DMSO- $d_{6}$ ) $\delta: 190.82,179.95,160.33,159.01,155.63,142.54,128.21,127.42,122.51$, 121.01, 111.70, 105.91, 61.55, 61.50; EI-MS: $m / z(\%): 365\left(\mathrm{M}^{+}, 45\right)$; Anal Calcd for $\mathrm{C}_{20} \mathrm{H}_{15} \mathrm{NO}_{6}$ (365.09): C, 65.75; H, 4.14; N, 3.83; found: C, 65.38; H, 3.91; N, 3.51 .

3-(2-Oxo-2-(4,6,7-trimethoxy-benzofuran-5-yl)-ethylidene)indolin-2-one (9b): Yield 60\%; orange powder; mp 93-5 ${ }^{\circ} \mathrm{C}$; IR (KBr, cm $\left.{ }^{-1}\right)$ : 3155 (s, 1H, NH), 1705, 1685 (C=O), $1552(\mathrm{C}=\mathrm{C}), 1160,1095(\mathrm{C}-\mathrm{O}-\mathrm{C}) ;{ }^{1} \mathrm{H}$ NMR (300 MHz, DMSO-d $\left.)_{6}\right) \delta: 10.79(\mathrm{~s}, 1 \mathrm{H}, \mathrm{NH}), 8.39$ (d, 1H, H-2 furan), 8.05 (d, 1H, Ar-H), 7.39 (t, 1H, Ar-H), 7.25 (d, 1H, Ar-H), 7.14 (s, 1H, CH), 7.02 (t, 1H, Ar-H), 6.90 (d, 1H, Ar-H), 4.00, 3.98, 3.81 $\left(3 \mathrm{~s}, 9 \mathrm{H}, \mathrm{OCH}_{3}\right) ;{ }^{13} \mathrm{C}$ NMR $\left(75 \mathrm{MHz}\right.$, DMSO-d $\left.d_{6}\right) \delta: 190.02,180.12,162.04,156.77,155.21,149.63,144.60$, 130.91, 129.01, 127.81, 121.71, 121.04, 110.54, 105.92, 61.00, 60.25, 60.07; EI-MS: $\mathrm{m} / z$ (\%): $379\left(\mathrm{M}^{+}, 42\right)$; Anal Calcd for $\mathrm{C}_{21} \mathrm{H}_{17} \mathrm{NO}_{6}$ (379.11): C, 66.49; $\mathrm{H}, 4.52 ; \mathrm{N}, 3.69$; found: $\mathrm{C}, 66.15 ; \mathrm{H}, 4.32 ; \mathrm{N}, 3.44$.

3-(2-(6-Ethoxy-4,7-dimethoxy-benzofuran-5-yl)-2-oxo-ethylidene)indolin-2-one (9c): Yield 33\%; orange powder; mp 118-2 ${ }^{\circ} \mathrm{C}$; IR $\left(\mathrm{KBr}, \mathrm{cm}^{-1}\right): 3212(\mathrm{~s}, 1 \mathrm{H}, \mathrm{NH}), 1698,1686(\mathrm{C}=\mathrm{O}), 1566(\mathrm{C}=\mathrm{C}), 1154,1033$ (C-O-C); ${ }^{1} \mathrm{H}$ NMR (300 MHz, DMSO- $d_{6}$ ) $\delta: 10.23$ (s, 1H, NH), 8.12 (d, 1H, H-2 furan), 7.85 (d, 1H, Ar-H), $7.35(\mathrm{t}, 1 \mathrm{H}, \mathrm{Ar}-\mathrm{H}), 7.27-6.97(\mathrm{~m}, 4 \mathrm{H}, \mathrm{Ar}-\mathrm{H}), 5.12\left(\mathrm{q}, 2 \mathrm{H}, \mathrm{CH}_{2}\right), 4.03\left(\mathrm{t}, 3 \mathrm{H}, \mathrm{CH}_{3}\right), 3.98,3.81(2 \mathrm{~s}, 6 \mathrm{H}$, $\mathrm{OCH}_{3}$ ); Anal Calcd for $\mathrm{C}_{22} \mathrm{H}_{19} \mathrm{NO}_{6}$ (393.39): C, 67.17; $\mathrm{H}, 4.87 ; \mathrm{N}, 3.56$; found: $\mathrm{C}, 67.02 ; \mathrm{H}, 4.71 ; \mathrm{N}, 3.44$.

3-(2-(N-Ethyl-1H-indol-3-yl)-2-oxo-ethylidene)indolin-2-one (10b):Yield 92\%; yellow powder; mp 197-9 ${ }^{\circ} \mathrm{C}$; IR (KBr, cm $\left.{ }^{-1}\right): 3100(\mathrm{NH}), 1695(\mathrm{C}=\mathrm{O}), 1585(\mathrm{C}=\mathrm{C}) ;{ }^{1} \mathrm{H}$ NMR $\left(300 \mathrm{MHz}, \mathrm{DMSO}-d_{6}\right) \delta: 10.90(\mathrm{~s}, 1 \mathrm{H}$, NH indolin-2-one), 8.54 (s, 1H, H-2 indole), 8.38-8.35 (m, 2H, Ar-H), 7.95 (s, 1H, CH), 7.63-7.13 (m, 6H, Ar-H), $4.37\left(\mathrm{t}, 2 \mathrm{H}, \mathrm{CH}_{2}\right), 1.54\left(\mathrm{q}, 3 \mathrm{H}, \mathrm{CH}_{3}\right)$; EI-MS: $\mathrm{m} / \mathrm{z}(\%): 316\left(\mathrm{M}^{+}, 32\right)$; Anal Calcd for $\mathrm{C}_{20} \mathrm{H}_{16} \mathrm{~N}_{2} \mathrm{O}_{2}$ (316.35): C, 75.93; H, 5.10; $\mathrm{N}, 8.86$; found: $\mathrm{C}, 75.73 ; \mathrm{H}, 4.92 ; \mathrm{N}, 8.65$.

3-(2-(N-Benzyl-1H-indol-3-yl)-2-oxo-ethylidene)indolin-2-one (10c): Yield $95 \%$, orange powder; mp 205-7 ${ }^{\circ} \mathrm{C}$; IR (KBr, cm $\left.{ }^{-1}\right): 3162(\mathrm{NH}), 1692(\mathrm{C}=\mathrm{O}), 1603(\mathrm{C}=\mathrm{C}) ;{ }^{1} \mathrm{H}$ NMR $\left(300 \mathrm{MHz}, \mathrm{DMSO}-d_{6}\right) \delta: 10.72(\mathrm{~s}, 1 \mathrm{H}$, $\mathrm{NH}), 8.87$ (s, 1H, H-2 indole), 8.42-8.37 (m, 2H, Ar-H), $7.67(\mathrm{~s}, 1 \mathrm{H}, \mathrm{CH}), 7.54-6.98(\mathrm{~m}, 11 \mathrm{H}, \mathrm{Ar}-\mathrm{H}), 5.65$ (s, $\left.2 \mathrm{H}, \mathrm{N}-\mathrm{CH}_{2}\right) ;{ }^{13} \mathrm{C}$ NMR (75 MHz, DMSO-d 6 ) $\delta: 189.37,180.62,159.35,140.81,138.46,137,04,130.98$, 
126.71, 123.45, 122.61, 122.12, 120.80, 120.68, 121.60, 121.32, 119.81, 42.03; EI-MS: $m / z(\%): 378\left(\mathrm{M}^{+}, 42\right)$; Anal Calcd for $\mathrm{C}_{25} \mathrm{H}_{18} \mathrm{~N}_{2} \mathrm{O}_{2}$ (378.42): C, 79.35; $\mathrm{H}, 4.79 ; \mathrm{N}, 7.40$; found: $\mathrm{C}, 79.14 ; \mathrm{H}, 4.57 ; \mathrm{N}, 7.22$.

3-(2-(N-Benzoyl-1H-indol-3-yl)-2-oxo-ethylidene)indolin-2-one (10d):Yield 62\%; brown powder; mp 252-4

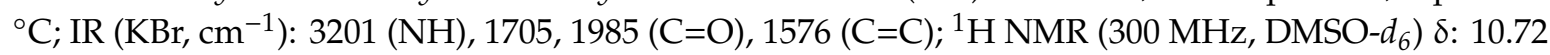
(s, 1H, NH), 8.56 (s, 1H, H-2 indole), 8.42-8.35 (m, 2H, Ar-H), 7.68 (s, 1H, CH), 7.53-6.95 (m, 11H, Ar-H); EI-MS: $m / z(\%): 392\left(\mathrm{M}^{+}, 12\right)$; Anal Calcd for $\mathrm{C}_{25} \mathrm{H}_{16} \mathrm{~N}_{2} \mathrm{O}_{3}$ (392.41): $\mathrm{C}, 76.52 ; \mathrm{H}, 4.11 ; \mathrm{N}, 7.14$; found: $\mathrm{C}$, 76.35; H, 4.02; N, 6.93 .

3-(2-(N-(2-Chloro-benzoyl)-1H-indol-3-yl)-2-oxo-ethylidene)indolin-2-one (10e): Yield 40\%; light brown powder; mp 228-30 ${ }^{\circ} \mathrm{C}$; IR $\left(\mathrm{KBr}, \mathrm{cm}^{-1}\right)$ : $3167(\mathrm{NH}), 1707,1665(\mathrm{C}=\mathrm{O}), 1572(\mathrm{C}=\mathrm{C}), 757(\mathrm{C}-\mathrm{Cl}) ;{ }^{1} \mathrm{H}$ NMR (300 MHz, DMSO- $d_{6}$ ) $\delta: 10.72$ (s, 1H, NH indolin-2-one), 8.56 (s, 1H, H-2 indole), 8.38-8.33 (m, 2H, Ar-H), 7.67 (s, 1H, CH), 7.35-6.85 (m, 10H, Ar-H); EI-MS: $m / z$ (\%): 426/428 (M+M+2, 5.87/3.1); Anal Calcd for $\mathrm{C}_{25} \mathrm{H}_{15} \mathrm{ClN}_{2} \mathrm{O}_{3}$ (426.85): $\mathrm{C}, 70.34 ; \mathrm{H}, 3.54 ; \mathrm{N}, 6.56$; found: $\mathrm{C}, 70.01 ; \mathrm{H}, 3.34 ; \mathrm{N}, 6.23$.

3-(2-(N-(4-Chloro-benzoyl)-1H-indol-3-yl)-2-oxo-ethylidene)indolin-2-one (10f):Yield 65\%; brown powder; $\mathrm{mp} 269-71^{\circ} \mathrm{C}$; IR (KBr, cm $\left.{ }^{-1}\right): 3155(\mathrm{NH}), 1705,1668$ (C=O), $1555(\mathrm{C}=\mathrm{C}), 752(\mathrm{C}-\mathrm{Cl}) ;{ }^{1} \mathrm{H}$ NMR (300 MHz, DMSO- $d_{6}$ ) $\delta: 10.72$ (s, 1H, NH indolin-2-one), 8.42 (s, 1H, H-2 indole), 8.42-8.38 (m, 2H, Ar-H), 7.67 (s, 1H, CH), 7.53-6.95 (m, 10H, Ar-H); ${ }^{13} \mathrm{C}$ NMR (75 MHz, DMSO-d 6 ) $\delta: 192.50,185.50,178,92$, 155.74, 152.03, 146.83, 143.91, 133.25, 130.04, 128.72, 127.78, 124.33, 122.98, 121.32, 112.18, 110.50; Anal Calcd for $\mathrm{C}_{25} \mathrm{H}_{15} \mathrm{ClN}_{2} \mathrm{O}_{3}$ (426.85): $\mathrm{C}, 70.34 ; \mathrm{H}, 3.54 ; \mathrm{N}, 6.56$; found: $\mathrm{C}, 70.02 ; \mathrm{H}, 3.21 ; \mathrm{N}, 6.23$.

3-(2-(N-(4-Bromo-benzenesulfonyl)-1H-indol-3-yl)-2-oxo-ethylidene)indolin-2-one (10g): Yield 50\%; brown crystal; mp 267-9 ${ }^{\circ} \mathrm{C}$; IR $\left(\mathrm{KBr}, \mathrm{cm}^{-1}\right)$ : $3168(\mathrm{NH}), 1696(\mathrm{C}=\mathrm{O}), 1581(\mathrm{C}=\mathrm{C}), 1375,1117\left(\mathrm{SO}_{2}\right), 782(\mathrm{C}-\mathrm{Br})$; ${ }^{1} \mathrm{H}$ NMR (300 MHz, DMSO-d 6 ) $\delta: 10.72$ (s, 1H, NH indolin-2-one), 8.56 (s, 1H, H-2 indole), 8.42-8.35 (m, $2 \mathrm{H}, \mathrm{Ar}-\mathrm{H}), 7.67(\mathrm{~s}, 1 \mathrm{H}, \mathrm{CH}), 7.53-6.86(\mathrm{~m}, 10 \mathrm{H}, \mathrm{Ar}-\mathrm{H}) ;{ }^{13} \mathrm{C}$ NMR $\left(75 \mathrm{MHz}, \mathrm{DMSO}-d_{6}\right) \delta: 188.56,179.90$, 152.74,145.72, 140.80, 138.53, 137.00, 135.42, 130.19, 127.19, 126.33, 123.92, 122.16, 120.59, 113.17, 110.40; Anal Calcd for $\mathrm{C}_{24} \mathrm{H}_{15} \mathrm{BrN}_{2} \mathrm{O}_{4} \mathrm{~S}$ (507.36): C, 56.82; H, 2.98; N, 5.52; found: C, 56.61; H, 3.11; N, 5.73 .

3-(2-(N-(4-Chloro-benzenesulfonyl)-1H-indol-3-yl)-2-oxo-ethylidene)indolin-2-one (10h): Yield 25\%; brown powder; $\mathrm{mp} 276-8{ }^{\circ} \mathrm{C}$; $\mathrm{IR}\left(\mathrm{KBr}, \mathrm{cm}^{-1}\right): 3201(\mathrm{NH}), 1685(\mathrm{C}=\mathrm{O}), 1576(\mathrm{C}=\mathrm{C}), 1375,1119\left(\mathrm{SO}_{2}\right), 775(\mathrm{C}-\mathrm{Cl})$; ${ }^{1} \mathrm{H}$ NMR $\left(300 \mathrm{MHz}\right.$, DMSO- $\left.d_{6}\right) \delta: 10.72$ (s, $1 \mathrm{H}, \mathrm{NH}$ indolin-2-one), 8.55 (s, $1 \mathrm{H}, \mathrm{H}-2$ indole), 8.39-8.35

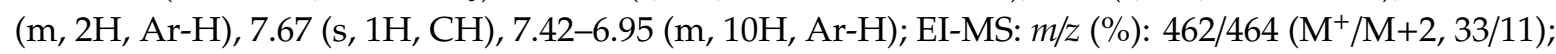
Anal Calcd for $\mathrm{C}_{24} \mathrm{H}_{15} \mathrm{ClN}_{2} \mathrm{O}_{4} \mathrm{~S}$ (462.90): C, 62.27; H, 3.27; N, 6.05; found: $\mathrm{C}, 62.01 ; \mathrm{H}, 3.11 ; \mathrm{N}, 5.86$.

3-(2-(N-(2-Nitro-benzenesulfonyl)-1H-indol-3-yl)-2-oxo-ethylidene)indolin-2-one (10i): Yield 20\%; reddish-brown powder; $\mathrm{mp} 189-90^{\circ} \mathrm{C}$; $\mathrm{IR}\left(\mathrm{KBr}, \mathrm{cm}^{-1}\right)$ : $3172(\mathrm{NH}), 1685(\mathrm{C}=\mathrm{O}), 1555(\mathrm{C}=\mathrm{C}), 1376,1117$ $\left(\mathrm{SO}_{2}\right) ;{ }^{1} \mathrm{H}$ NMR (300 MHz, DMSO- $\left.d_{6}\right) \delta: 10.72$ (s, $1 \mathrm{H}, \mathrm{NH}$ indolin-2-one), 8.56 (s, 1H, H-2 indole), 8.45-8.35 (m, 2H, Ar-H), 7.67 (s, 1H, CH), 7.41-6.96 (m, 10H, Ar-H); EI-MS: m/z (\%): 473 (M+ , 5); Anal Calcd for $\mathrm{C}_{24} \mathrm{H}_{15} \mathrm{~N}_{3} \mathrm{O}_{6} \mathrm{~S}$ (473.46): C, 60.88; H, 3.19; N, 8.88; found: $\mathrm{C}, 60.52 ; \mathrm{H}, 2.95 ; \mathrm{N}, 8.53$.

3.3.3. General Procedure for the Synthesis of 2', $4^{\prime}$-dihydrospiro(indoline-3,3'-pyrazol)-2-one Derivatives 11a-c, 12a-c and 13a-i

To a mixture of compound $\mathbf{8 a}-\mathbf{c}, \mathbf{9 a}-\mathbf{c}$ and $\mathbf{1 0 a}-\mathbf{i}(10 \mathrm{mmol})$ and hydrazine hydrate $(50 \mathrm{mmol})$ in absolute ethanol $(10 \mathrm{~mL})$, a few drops of glacial acetic acid were added, and the reaction mixture was refluxed for 4-6 h. After cooling, the reaction mixture was poured onto ice-water, and the solid that formed was filtered off, washed with water, air-dried and crystallized from ethyl acetate-cyclohexane (1:1).

5'-(6-Hydroxy-4-methoxy-benzofuran-5-yl)-2',4'-dihydrospiro(indoline-3,3'-pyrazol)-2-one (11a): Yield 87\%; orange powder; $\mathrm{mp} 129-31^{\circ} \mathrm{C}$; IR $\left(\mathrm{KBr}, \mathrm{cm}^{-1}\right)$ : $3554(\mathrm{OH}), 3228,3155(\mathrm{NH}), 1699(\mathrm{C}=\mathrm{O}), 1618(\mathrm{C}=\mathrm{N})$, 1550 (C=C), 1048, 1117 (C-O-C); ${ }^{1} \mathrm{H}$ NMR (300 MHz, DMSO-d 6 ) $8: 11.77$ (s, 1H, OH), 10.99 (s, 1H, $\mathrm{NH}), 10.27$ (s, 1H, NH), 7.93 (d, 1H, H-2 furan), 7.52 (d, 1H Ar-H), 7.34-7.02 (m, 3H, Ar-H), 6.97 (d, $1 \mathrm{H}, \mathrm{Ar}-\mathrm{H}), 6.74(\mathrm{~s}, 1 \mathrm{H}, \mathrm{Ar}-\mathrm{H}), 5.95\left(\mathrm{~s}, 2 \mathrm{H}, \mathrm{CH}_{2}\right), 4.14\left(\mathrm{~s}, 3 \mathrm{H}, \mathrm{OCH}_{3}\right) ;{ }^{13} \mathrm{C} \mathrm{NMR}\left(75 \mathrm{MHz}, \mathrm{DMSO}-d_{6}\right) \delta$ : 
180.21, 165.35, 160.94, 154.62, 152.05, 145.36, 143.21, 132.32, 130.04, 128.57, 127.08, 122.06, 120.19, 105.91, 93.85, 64.50, 60.26, 45.56; EI-MS: $m / z(\%): 363\left(\mathrm{M}^{+}, 13\right)$; Anal Calcd for $\mathrm{C}_{19} \mathrm{H}_{15} \mathrm{~N}_{3} \mathrm{O}_{4}$ (349.34): $\mathrm{C}, 65.32$; $\mathrm{H}, 4.33 ; \mathrm{N}, 12.03$; found: $\mathrm{C}, 65.17 ; \mathrm{H}, 4.21 ; \mathrm{N}, 11.92$.

5'-(4,6-Dimethoxy-benzofuran-5-yl)-2',4'-dihydrospiro(indoline-3,3'-pyrazol)-2-one (11b): Yield 65\%; yellow powder; $\mathrm{mp} 180-2{ }^{\circ} \mathrm{C}$; IR $\left(\mathrm{KBr}, \mathrm{cm}^{-1}\right): 3279,3120(\mathrm{NH}), 1685(\mathrm{C}=\mathrm{O}), 1617(\mathrm{C}=\mathrm{N}) 1558(\mathrm{C}=\mathrm{C}), 1060$, 1139 (C-O-C); ${ }^{1} \mathrm{H}$ NMR (300 MHz, DMSO-d $\left.d_{6}\right) \delta: 11.02(\mathrm{~s}, 1 \mathrm{H}, \mathrm{NH}), 10.02(\mathrm{~s}, 1 \mathrm{H}, \mathrm{NH}), 8.01$ (d, $1 \mathrm{H}, \mathrm{H}-2$ furan), $7.61(\mathrm{~d}, 1 \mathrm{H} \mathrm{Ar}-\mathrm{H}), 7.51-6.66(\mathrm{~m}, 5 \mathrm{H}, \mathrm{Ar}-\mathrm{H}), 5.52\left(\mathrm{~s}, 2 \mathrm{H}, \mathrm{CH}_{2}\right), 4.14,4.05\left(2 \mathrm{~s}, 6 \mathrm{H}, \mathrm{OCH}_{3}\right)$; EI-MS: $\mathrm{m} / \mathrm{z}(\%): 363\left(\mathrm{M}^{+}, 12\right)$; Anal Calcd for $\mathrm{C}_{20} \mathrm{H}_{17} \mathrm{~N}_{3} \mathrm{O}_{4}$ (363.37): $\mathrm{C}, 66.11 ; \mathrm{H}, 4.72 ; \mathrm{N}, 11.56$; found: $\mathrm{C}, 66.01$; $\mathrm{H}, 4.61 ; \mathrm{N}, 11.44$.

5'-(6-Ethoxy-4-methoxy-benzofuran-5-yl)-2',4'-dihydrospiro(indoline-3,3'-pyrazol)-2-one (11c): Yield 51\%; gray powder; $\mathrm{mp} 137-9{ }^{\circ} \mathrm{C}$; IR $\left(\mathrm{KBr}, \mathrm{cm}^{-1}\right)$ : 3222, $3124(\mathrm{NH}), 1693(\mathrm{C}=\mathrm{O}), 1620(\mathrm{C}=\mathrm{N}), 1562(\mathrm{C}=\mathrm{C})$, 1060, 1137 (C-O-C); ${ }^{1} \mathrm{H}$ NMR (300 MHz, DMSO-d 6 ) $8: 9.72$ (s, 1H, NH), 8.29 (s, 1H, NH), 7.93 (d, 1H, H-2 furan), $7.62(\mathrm{~d}, 1 \mathrm{H} \mathrm{Ar}-\mathrm{H}), 7.50(\mathrm{t}, 1 \mathrm{H}, \mathrm{Ar}-\mathrm{H}), 7.48(\mathrm{~d}, 1 \mathrm{H}, \mathrm{Ar}-\mathrm{H}), 7.35-6.92(\mathrm{~m}, 3 \mathrm{H}, \mathrm{Ar}-\mathrm{H}), 5.25(\mathrm{~s}, 2 \mathrm{H}$, $\left.\mathrm{CH}_{2}\right), 5.15\left(\mathrm{q}, 2 \mathrm{H}, \mathrm{OCH}_{2}\right), 4.03\left(\mathrm{t}, 3 \mathrm{H}, \mathrm{CH}_{3}\right), 3.77\left(\mathrm{~s}, 3 \mathrm{H}, \mathrm{OCH}_{3}\right)$; Anal Calcd for $\mathrm{C}_{21} \mathrm{H}_{19} \mathrm{~N}_{3} \mathrm{O}_{4}$ (377.39): C, 66.83; H, 5.07; N, 11.13; found: C, 66.65; H, 5.13; N, 11.02 .

5'-(6-Hydroxy-4,7-dimethoxy-benzofuran-5-yl)-2',4'-dihydrospiro(indoline-3,3'-pyrazol)-2-one (12a): Yield $45 \%$; yellowish-brown powder; $\mathrm{mp} 270-2{ }^{\circ} \mathrm{C}$; IR $\left(\mathrm{KBr}, \mathrm{cm}^{-1}\right)$ : $3445(\mathrm{OH}), 3185,3165(\mathrm{NH}), 1685(\mathrm{C}=\mathrm{O})$, $1618(\mathrm{C}=\mathrm{N}), 1557(\mathrm{C}=\mathrm{C}), 1153,1132(\mathrm{C}-\mathrm{O}-\mathrm{C}){ }^{1}{ }^{1} \mathrm{H}$ NMR (300 MHz, DMSO-d 6 ) $\delta: 10.67$ (s, 1H, OH), 10.47, $10.23(2 \mathrm{~s}, 2 \mathrm{H}, 2 \mathrm{NH}), 7.95$ (d, 1H, H-2 furan), 7.88 (d, 1H, Ar-H), 7.30-6.65 (m, 4H, Ar-H), 5.41 (s, 2H, $\left.\mathrm{CH}_{2}\right), 4.26,4.19\left(2 \mathrm{~s}, 6 \mathrm{H}, \mathrm{OCH}_{3}\right) ;{ }^{13} \mathrm{C}$ NMR $\left(75 \mathrm{MHz}, \mathrm{DMSO}-d_{6}\right) \delta: 184.52,167.54,160.19,155.61,145.52$, 132.25, 130.05, 127.81, 127.06, 124.92, 121.25, 105.85, 63.92, 61.64, 60.25, 45.75; EI-MS: $\mathrm{m} / \mathrm{z}(\%): 379\left(\mathrm{M}^{+}\right.$, 29); Anal Calcd for $\mathrm{C}_{20} \mathrm{H}_{17} \mathrm{~N}_{3} \mathrm{O}_{5}$ (379.12): $\mathrm{C}, 63.32 ; \mathrm{H}, 4.52 ; \mathrm{N}, 11.08$; found: $\mathrm{C}, 63.07 ; \mathrm{H}, 4.33 ; \mathrm{N}, 10.95$.

5'-(4,6,7-Trimethoxy-benzofuran-5-yl)-2',4'-dihydrospiro(indoline-3,3'-pyrazol)-2-one (12b): Yield 62\%; orange powder; mp $145-7{ }^{\circ} \mathrm{C}$; IR $\left(\mathrm{KBr}, \mathrm{cm}^{-1}\right)$ : 3206, $3175(\mathrm{NH}), 1687(\mathrm{C}=\mathrm{O}), 1618(\mathrm{C}=\mathrm{N}), 1545$ $(\mathrm{C}=\mathrm{C}), 1163,1034(\mathrm{C}-\mathrm{O}-\mathrm{C}) ;{ }^{1} \mathrm{H}$ NMR $\left(300 \mathrm{MHz}, \mathrm{DMSO}-d_{6}\right) \delta: 12.31,10.39(\mathrm{~s}, 2 \mathrm{H}, 2 \mathrm{NH}), 8.40(\mathrm{~d}, 1 \mathrm{H}, \mathrm{H}-2$ furan), $7.99(\mathrm{~d}, 1 \mathrm{H}, \mathrm{Ar}-\mathrm{H}), 7.59(\mathrm{t}, 1 \mathrm{H}, \mathrm{Ar}-\mathrm{H}), 7.40-6.85(\mathrm{~m}, 3 \mathrm{H}, \mathrm{Ar}-\mathrm{H}), 4.04\left(\mathrm{~s}, 2 \mathrm{H}, \mathrm{CH}_{2}\right), 3.99,3.92,3.84$ (3s, 9H, 3OCH 3 ); Anal Calcd for $\mathrm{C}_{21} \mathrm{H}_{19} \mathrm{~N}_{3} \mathrm{O}_{5}$ (393.39): C, 64.12; $\mathrm{H}, 4.87 ; \mathrm{N}, 10.68$; found: $\mathrm{C}, 64.01 ; \mathrm{H}$, $4.71 ; \mathrm{N}, 10.53$.

5'-(6-Ethoxy-4,7-dimethoxy-benzofuran-5-yl)-2',4'-dihydrospiro(indoline-3,3'-pyrazol)-2-one (12c): Yield 42\%; orange powder; $\mathrm{mp} 135-7^{\circ} \mathrm{C}$; IR $\left(\mathrm{KBr}, \mathrm{cm}^{-1}\right)$ : 3210, $3165(\mathrm{NH}), 1685(\mathrm{C}=\mathrm{O}), 1620(\mathrm{C}=\mathrm{N}), 1555(\mathrm{C}=\mathrm{C})$, 1163, 1035 (C-O-C); ${ }^{1} \mathrm{H}$ NMR (300 MHz, DMSO- $d_{6}$ ) $\delta: 12.23,10.20$ (s, 2H, 2NH), 8.25 (d, 1H, H-2 furan), $7.78(\mathrm{~d}, 1 \mathrm{H}, \mathrm{Ar}-\mathrm{H}), 7.41(\mathrm{~d}, 1 \mathrm{H}, \mathrm{Ar}-\mathrm{H}), 7.25-7.13(\mathrm{~m}, 2 \mathrm{H}, \mathrm{Ar}-\mathrm{H}), 6.85(\mathrm{~d}, 1 \mathrm{H}, \mathrm{Ar}-\mathrm{H}), 5.50\left(\mathrm{~s}, 2 \mathrm{H}, \mathrm{CH}_{2}\right)$, $5.02\left(\mathrm{q}, 2 \mathrm{H}, \mathrm{OCH}_{2}\right), 4.02\left(\mathrm{t}, 3 \mathrm{H}, \mathrm{CH}_{3}\right), 3.83,3.76\left(2 \mathrm{~s}, 6 \mathrm{H}, \mathrm{OCH}_{3}\right) ; \mathrm{EI}-\mathrm{MS}: \mathrm{m} / z(\%): 407\left(\mathrm{M}^{+}, 22\right)$; Anal Calcd for $\mathrm{C}_{22} \mathrm{H}_{21} \mathrm{~N}_{3} \mathrm{O}_{5}$ (407.42): C, 64.86; H, 5.20; N, 10.31; found: C, 64.71; H, 5.05; N, 10.17 .

5'-(1H-Indol-3-yl)-2',4'-dihydrospiro(indoline-3,3'-pyrazol)-2-one (13a): Yield 65\%; orange powder; $\mathrm{mp}$ 318-20 ${ }^{\circ} \mathrm{C}$; IR $\left(\mathrm{KBr}, \mathrm{cm}^{-1}\right): 3261,3157(\mathrm{NH}), 1696(\mathrm{C}=\mathrm{O}), 1618(\mathrm{C}=\mathrm{N}), 1573(\mathrm{C}=\mathrm{C}) ;{ }^{1} \mathrm{H}$ NMR $(300 \mathrm{MHz}$, DMSO- $\left.d_{6}\right) \delta: 12.54,11.87,10.40(3 \mathrm{~s}, 3 \mathrm{H}, 3 \mathrm{NH}), 8.91(\mathrm{~d}, 1 \mathrm{H}, \mathrm{Ar}-\mathrm{H}), 8.53$ (s, 1H, H-2 indole), 8.39 (d, 1H, Ar-H), 8.17 (d, 1H, Ar-H), 7.57-7.12 (m, 5H, Ar-H), $5.45\left(\mathrm{~s}, 2 \mathrm{H}, \mathrm{CH}_{2}\right) ;{ }^{13} \mathrm{C}$ NMR $\left(75 \mathrm{MHz}\right.$, DMSO- $\left.d_{6}\right) \delta$ : 179.75, 152.62, 142.66, 138.12, 127.81, 127.65, 124.62, 122.66, 121.32, 120.65, 112.05, 111.42, 62.50, 41.73; EI-MS: $m / z(\%)$ : $302\left(\mathrm{M}^{+}, 43\right)$; Anal Calcd for $\mathrm{C}_{18} \mathrm{H}_{14} \mathrm{~N}_{4} \mathrm{O}$ (302.33): $\mathrm{C}, 71.51 ; \mathrm{H}, 4.67 ; \mathrm{N}, 18.53$; found: $\mathrm{C}$, 71.33; $\mathrm{H}, 4.31 ; \mathrm{N}, 18.27$.

5'-(N-Ethyl-1H-indol-3-yl)-2',4'-dihydrospiro(indoline-3,3'-pyrazol)-2-one (13b): Yield 63\%; orange powder; mp 143-5 ${ }^{\circ} \mathrm{C}$; IR $\left(\mathrm{KBr}, \mathrm{cm}^{-1}\right)$ : 3212, $3126(\mathrm{NH}), 1696(\mathrm{C}=\mathrm{O}), 1618(\mathrm{C}=\mathrm{N}), 1573(\mathrm{C}=\mathrm{C}) ;{ }^{1} \mathrm{H}$ NMR $(300$ MHz, DMSO- $\left.d_{6}\right) \delta: 12.17,10.91(2 \mathrm{~s}, 2 \mathrm{H}, 2 \mathrm{NH}), 8.93(\mathrm{~d}, 1 \mathrm{H}, \mathrm{Ar}-\mathrm{H}), 8.54(\mathrm{~s}, 1 \mathrm{H}, \mathrm{Ar}-\mathrm{H}), 8.38-7.13(\mathrm{~m}, 7 \mathrm{H}$, Ar-H), 4.37-4.19 (m, 4H, 2CH $), 1.54\left(\mathrm{t}, 3 \mathrm{H}, \mathrm{CH}_{3}\right)$; Anal Calcd for $\mathrm{C}_{20} \mathrm{H}_{18} \mathrm{~N}_{4} \mathrm{O}$ (330.38): C, 72.71; $\mathrm{H}, 5.49$; $\mathrm{N}, 16.96$; found: $\mathrm{C}, 72.56 ; \mathrm{H}, 5.32 ; \mathrm{N}, 16.80$. 
5'-(N-Benzyl-1H-indol-3-yl)-2',4'-dihydrospiro(indoline-3,3'-pyrazol)-2-one (13c): Yield 80\%; orange powder; mp 83-5 ${ }^{\circ} \mathrm{C}$; IR $\left(\mathrm{KBr}, \mathrm{cm}^{-1}\right)$ : 3284, $3127(\mathrm{NH}), 1676(\mathrm{C}=\mathrm{O}), 1618(\mathrm{C}=\mathrm{N}), 1556(\mathrm{C}=\mathrm{C}) ;{ }^{1} \mathrm{H}$ NMR $(300 \mathrm{MHz}$, DMSO- $\left.d_{6}\right) \delta: 10.72,8.92(2 \mathrm{~s}, 2 \mathrm{H}, 2 \mathrm{NH}), 8.53(\mathrm{~s}, 1 \mathrm{H}, \mathrm{H}-2$ indole), $8.44(\mathrm{~m}, 2 \mathrm{H}, \mathrm{Ar}-\mathrm{H}), 8.20(\mathrm{t}, 1 \mathrm{H}, \mathrm{Ar}-\mathrm{H})$, $7.81(\mathrm{~d}, 1 \mathrm{H}, \mathrm{Ar}-\mathrm{H}), 7.67(\mathrm{~d}, 1 \mathrm{H}, \mathrm{Ar}-\mathrm{H}), 7.56-6.87(\mathrm{~m}, 8 \mathrm{H}, \mathrm{Ar}-\mathrm{H}), 5.56,5.50\left(2 \mathrm{~s}, 4 \mathrm{H}, 2 \mathrm{CH}_{2}\right) ;{ }^{13} \mathrm{C}$ NMR $(75$ MHz, DMSO- $d_{6}$ ) $\delta: 180.05,151.75,142.15,138.55,137.72,130.01,128.40,127.21,126.04,122.72,121.23$, 120.07, 110.71, 63.00, 44.59, 41.35; EI-MS: $\mathrm{m} / z$ (\%): $392\left(\mathrm{M}^{+}, 43\right)$; Anal Calcd for $\mathrm{C}_{25} \mathrm{H}_{20} \mathrm{~N}_{4} \mathrm{O}$ (392.45): C, 76.51; H, 5.14; N, 14.28; found: C, 76.51; H, 5.14; N, 14.28 .

5'-(N-Benzoyl-1H-indol-3-yl)-2',4'-dihydrospiro(indoline-3,3'-pyrazol)-2-one (13d): Yield 52\%; brown powder; mp 307-9 ${ }^{\circ} \mathrm{C}$; IR $\left(\mathrm{KBr}, \mathrm{cm}^{-1}\right)$ : 3262, $3125(\mathrm{NH}), 1687(\mathrm{C}=\mathrm{O}), 1618(\mathrm{C}=\mathrm{N}), 1576(\mathrm{C}=\mathrm{C})$; ${ }^{1} \mathrm{H}$ NMR $\left(300 \mathrm{MHz}\right.$, DMSO- $\left.d_{6}\right) \delta:$ 11.54, 10.72 (2s, 2H, 2NH), 8.55 (d, 1H, Ar-H), 8.39-8.33 (m, 2H, Ar-H), 7.53 (m, 2H, Ar-H), 7.34-6.86 (m, 9H, Ar-H), 5.05 (s, 2H, $\left.\mathrm{CH}_{2}\right)$; EI-MS: $m / z(\%): 406\left(\mathrm{M}^{+}, 21\right)$; Anal Calcd for $\mathrm{C}_{25} \mathrm{H}_{18} \mathrm{~N}_{4} \mathrm{O}_{2}$ (406.44): $\mathrm{C}, 73.88 ; \mathrm{H}, 4.46 ; \mathrm{N}, 13.78$; found: $\mathrm{C}, 73.65 ; \mathrm{H}, 4.32 ; \mathrm{N}, 13.63$.

5'-(N-(2-Chloro-benzoyl)-1H-indol-3-yl)-2',4'-dihydrospiro(indoline-3,3'-pyrazol)-2-one (13e): Yield 45\%; brown powder; $\mathrm{mp} 219-21{ }^{\circ} \mathrm{C}$; IR $\left(\mathrm{KBr}, \mathrm{cm}^{-1}\right): 3212,3156(\mathrm{NH}), 1707,1687(\mathrm{C}=\mathrm{O}), 1620(\mathrm{C}=\mathrm{N}), 1535$ $(\mathrm{C}=\mathrm{C}), 752(\mathrm{C}-\mathrm{Cl}) ;{ }^{1} \mathrm{H}$ NMR (300 MHz, DMSO- $\left.d_{6}\right) \delta:$ 11.55, 10.72 (2s, 2H, NH), 8.23 (s, 1H, H-2 indole), $8.02(\mathrm{~m}, 2 \mathrm{H}, \mathrm{Ar}-\mathrm{H}), 7.85$ (d, 1H, Ar-H), 7.35-6.85 (m, 9H, Ar-H), $4.67\left(\mathrm{~s}, 2 \mathrm{H}, \mathrm{CH}_{2}\right) ;{ }^{13} \mathrm{C} \mathrm{NMR}(75 \mathrm{MHz}$, DMSO- $\left.d_{6}\right) \delta:$ 190.00, 179.73, 151.82, 142.62, 140.16, 139.21, 138.50, 134.21, 129.44, 127.05, 122.91, 122.51, 120.16, 112.56, 110.71, 62.65, 42.08; Anal Calcd for $\mathrm{C}_{25} \mathrm{H}_{17} \mathrm{ClN}_{4} \mathrm{O}_{2}$ (440.88): C, 68.11; $\mathrm{H}, 3.89 ; \mathrm{N}, 12.71$; found: $\mathrm{C}, 68.02 ; \mathrm{H}, 3.77 ; \mathrm{N}, 12.63$.

5'-(N-(4-Chloro-benzoyl)-1H-indol-3-yl)-2',4'-dihydrospiro(indoline-3,3'-pyrazol)-2-one (13f): Yield 50\%; off-white crystals; mp 202-4 ${ }^{\circ} \mathrm{C}$; IR $\left(\mathrm{KBr}, \mathrm{cm}^{-1}\right)$ : 3205, $3154(\mathrm{NH}), 1705,1688(\mathrm{C}=\mathrm{O}), 1618(\mathrm{C}=\mathrm{N}), 1575$ $(\mathrm{C}=\mathrm{C}), 752(\mathrm{C}-\mathrm{Cl}) ;{ }^{1} \mathrm{H}$ NMR $\left(300 \mathrm{MHz}, \mathrm{DMSO}-d_{6}\right) \delta: 10.72,9.52(2 \mathrm{~s}, 2 \mathrm{H}, 2 \mathrm{NH}), 8.32$ (s, 1H, H-2 indole), $8.12(\mathrm{~m}, 2 \mathrm{H}, \mathrm{Ar}-\mathrm{H}), 7.87(\mathrm{~m}, 3 \mathrm{H}, \mathrm{Ar}-\mathrm{H}), 7.61-6.85(\mathrm{~m}, 7 \mathrm{H}, \mathrm{Ar}-\mathrm{H}), 5.01$ (s, 2H, CH$)_{2}$; EI-MS: $\mathrm{m} / z(\%)$ : 440/442 ( $\left.\mathrm{M}^{+}, 21 / 7\right)$; Anal Calcd for $\mathrm{C}_{25} \mathrm{H}_{17} \mathrm{ClN}_{4} \mathrm{O}_{2}$ (440.88): $\mathrm{C}, 68.11 ; \mathrm{H}, 3.89 ; \mathrm{N}, 12.71$; found: $\mathrm{C}, 67.94$; $\mathrm{H}, 3.67 ; \mathrm{N}, 12.56$.

5'-(N-(4-Bromo-benzenesulfonyl)-1H-indol-3-yl)-2',4'-dihydrospiro(indoline-3,3'-pyrazol)-2-one (13g):Yield 35\%; orange powder; $\mathrm{mp} \mathrm{190-2}{ }^{\circ} \mathrm{C}$; IR $\left(\mathrm{KBr}, \mathrm{cm}^{-1}\right)$ : $3268(\mathrm{NH}), 1687(\mathrm{C}=\mathrm{O}), 1620(\mathrm{C}=\mathrm{N}), 1585(\mathrm{C}=\mathrm{C})$, 1367, $1132\left(\mathrm{SO}_{2}\right), 785(\mathrm{C}-\mathrm{Br}){ }^{1} \mathrm{H}$ NMR (300 MHz, DMSO- $\left.d_{6}\right) \delta: 11.52,10.72(2 \mathrm{~s}, 2 \mathrm{H}, 2 \mathrm{NH}), 8.31(\mathrm{~s}, 1 \mathrm{H}$, $\mathrm{H}-2$ indole), 8.02-7.95 (m, 2H, Ar-H), 7.64-6.91 (m, 10H, Ar-H), $4.75\left(\mathrm{~s}, 2 \mathrm{H}, \mathrm{CH}_{2}\right) ;{ }^{13} \mathrm{C}$ NMR $(75 \mathrm{MHz}$, DMSO- $\left.d_{6}\right) \delta:$ 178.91, 152.05, 142.52, 140.01, 138.06, 137.27, 130.47, 129.42, 127.18, 122.06, 121.15, 120.11, 110.07, 64.00, 42.21; Anal Calcd for $\mathrm{C}_{24} \mathrm{H}_{17} \mathrm{BrN}_{4} \mathrm{O}_{3} \mathrm{~S}$ (521.39): C, 55.29; H, 3.29; N, 10.75; found: $\mathrm{C}, 55.29$; $\mathrm{H}, 3.29 ; \mathrm{N}, 10.75$.

5'-(N-(4-Chloro-benzensulfonyl)-1H-indol-3-yl)-2',4'-dihydrospiro(indoline-3,3'-pyrazol)-2-one (13h): Yield 35\%; orange powder; $\mathrm{mp} 197-9{ }^{\circ} \mathrm{C}$; IR $\left(\mathrm{KBr}, \mathrm{cm}^{-1}\right): 3251,3153(\mathrm{NH}), 1675(\mathrm{C}=\mathrm{O}), 1618(\mathrm{C}=\mathrm{N}), 1565$ $(\mathrm{C}=\mathrm{C}), 1345,1132\left(\mathrm{SO}_{2}\right), 775(\mathrm{C}-\mathrm{Cl}) ;{ }^{1} \mathrm{H}$ NMR $\left(300 \mathrm{MHz}, \mathrm{DMSO}-d_{6}\right)$ 8: 9.75, $10.72(2 \mathrm{~s}, 2 \mathrm{H}, 2 \mathrm{NH}), 8.45(\mathrm{~s}$, 1H, H-2 indole), 7.99-6.85 (m, 12H, Ar-H), 5.61 (s, 2H, $\left.\mathrm{CH}_{2}\right)$; EI-MS: $m / z(\%): 476 / 478\left(\mathrm{M}^{+} / \mathrm{M}+2,27 / 9\right)$; Anal Calcd for. $\mathrm{C}_{24} \mathrm{H}_{17} \mathrm{ClN}_{4} \mathrm{O}_{3} \mathrm{~S}$ (476.93): $\mathrm{C}, 60.44 ; \mathrm{H}, 3.59 ; \mathrm{N}, 11.75$; found: $\mathrm{C}, 60.28 ; \mathrm{H}, 3.41 ; \mathrm{N}, 11.57$.

5'-(N-(2-Nitro-benzensulfonyl)-1H-indol-3-yl)-2',4'-dihydrospiro (indoline-3,3'-pyrazol)-2-one (13i):Yield 35\%; brown powder; $\mathrm{mp} 210-2{ }^{\circ} \mathrm{C}$; IR $\left(\mathrm{KBr}, \mathrm{cm}^{-1}\right)$ : 3227, $3156(\mathrm{NH}), 1685(\mathrm{C}=\mathrm{O}), 1618(\mathrm{C}=\mathrm{N}), 1575(\mathrm{C}=\mathrm{C})$, 1376, $1117\left(\mathrm{SO}_{2}\right) ;{ }^{1} \mathrm{H}$ NMR (300 MHz, DMSO-d 6 ) $\delta: 11.51,10.72$ (2s, 2H, 2NH), 8.50 (s, 1H, H-2 indole), 8.37-7.14 (m, $12 \mathrm{H}, \mathrm{Ar}-\mathrm{H}), 5.32$ (2s, $\left.2 \mathrm{H}, \mathrm{CH}_{2}\right)$; EI-MS: $\mathrm{m} / \mathrm{z}(\%)$ : 487( $\left.\mathrm{M}^{+}, 21\right)$; Anal Calcd for. $\mathrm{C}_{24} \mathrm{H}_{17} \mathrm{~N}_{5} \mathrm{O}_{5} \mathrm{~S}$ (487.49): C, 59.13; H, 3.51; N, 14.37; found: C, 59.01; H, 3.43; N, 14.26.

3.3.4. General Procedure for the Synthesis of 2'-phenyl-2', 4'-dihydrospiro(indoline-3,3'-pyrazol)-2-ones 14a-i

Compounds 14a-i prepared according to previously described methods for compounds 13a-i using an equimolar mixture of compounds $10 \mathbf{a}-\mathbf{i}(10 \mathrm{mmol})$ and phenyl hydrazine (50 mmol). 
5'-(1H-Indol-3-yl)-2'-phenyl-2',4'-dihydrospiro(indoline-3,3'-pyrazol)-2-one (14a): Yield 52\%; orange powder; mp 124-6 ${ }^{\circ} \mathrm{C}$; IR $\left(\mathrm{KBr}, \mathrm{cm}^{-1}\right): 3186(\mathrm{NH}), 1701(\mathrm{C}=\mathrm{O}), 1620(\mathrm{C}=\mathrm{N}), 1565(\mathrm{C}=\mathrm{C}) ;{ }^{1} \mathrm{H}$ NMR $(300 \mathrm{MHz}$, DMSO- $\left.d_{6}\right) \delta:$ 11.62, $10.72(2 \mathrm{~s}, 2 \mathrm{H}, 2 \mathrm{NH}), 8.22(\mathrm{~d}, 1 \mathrm{H}, \mathrm{Ar}-\mathrm{H}), 8.05$ (s, 1H, H-2), $7.92(\mathrm{~m}, 1 \mathrm{H}, \mathrm{Ar}-\mathrm{H}), 7.89$ (d, 1H, Ar-H), 7.82 (d, 1H, Ar-H), 7.64 (m, 1H, Ar-H),7.53 (d, 1H, Ar-H), 7.46-7.12 (m, 7H, Ar-H), 5.28 (s, 2H, $\left.\mathrm{CH}_{2}\right) ;{ }^{13} \mathrm{C}$ NMR $\left(75 \mathrm{MHz}\right.$, DMSO-d $\left.d_{6}\right) \delta: 197.72,152.31,144.05,142.15,139.61,137.72,128.46$, 128.04, 127.26, 122.71, 121.36, 121.01, 110.07, 68.71, 40.95; EI-MS: $\mathrm{m} / \mathrm{z}(\%): 378$ (M+ $\left.{ }^{+}, 22\right)$; Anal Calcd for. $\mathrm{C}_{24} \mathrm{H}_{18} \mathrm{~N}_{4} \mathrm{O}$ (378.43): C, 76.17; H, 4.79; N, 14.81; found: $\mathrm{C}, 76.02 ; \mathrm{H}, 4.61 ; \mathrm{N}, 14.65$.

5'-(N-Ethyl-1H-indol-3-yl)-2'-phenyl-2',4'-dihydrospiro(indoline-3,3'-pyrazol)-2-one (14b): Yield 51\%; reddish-brown powder; $\mathrm{mp} 108-10^{\circ} \mathrm{C}$; $\mathrm{IR}\left(\mathrm{KBr}, \mathrm{cm}^{-1}\right)$ : $3196(\mathrm{NH}), 1678(\mathrm{C}=\mathrm{O}), 1618(\mathrm{C}=\mathrm{N}), 1556(\mathrm{C}=\mathrm{C})$; ${ }^{1} \mathrm{H}$ NMR $\left(300 \mathrm{MHz}, \mathrm{DMSO}_{-} \mathrm{d}_{6}\right) \delta: 10.52(\mathrm{~s}, \mathrm{H}, \mathrm{NH}), 8.2(\mathrm{~d}, 1 \mathrm{H}, \mathrm{Ar}-\mathrm{H}), 8.22(\mathrm{~s}, 1 \mathrm{H}, \mathrm{Ar}-\mathrm{H}), 8.04-7.12(\mathrm{~m}$, 7H, Ar-H), $5.21\left(\mathrm{~s}, 2 \mathrm{H}, \mathrm{CH}_{2}\right), 4.21$ (q, 2H, $\left.\mathrm{CH}_{2}\right), 1.54\left(\mathrm{t}, 3 \mathrm{H}, \mathrm{CH}_{3}\right)$; EI-MS: $m / z(\%): 406\left(\mathrm{M}^{+}, 22\right)$; Anal Calcd for $\mathrm{C}_{26} \mathrm{H}_{22} \mathrm{~N}_{4} \mathrm{O}$ (406.48): C, 76.83; $\mathrm{H}, 5.46 ; \mathrm{N}, 13.78$; found: $\mathrm{C}, 76.71 ; \mathrm{H}, 5.26 ; \mathrm{N}, 13.50$.

5'-(N-Benzyl-1H-indol-3-yl)-2'-phenyl-2',4'-dihydrospiro(indoline-3,3'-pyrazol)-2-one (14c): Yield 60\%; brown powder; mp 96-8 ${ }^{\circ} \mathrm{C}$; IR $\left(\mathrm{KBr}, \mathrm{cm}^{-1}\right)$ : $3165(\mathrm{NH}), 1676(\mathrm{C}=\mathrm{O}), 1618(\mathrm{C}=\mathrm{N}), 1558(\mathrm{C}=\mathrm{C})$; ${ }^{1} \mathrm{H}$ NMR (300 MHz, DMSO- $\left.d_{6}\right) \delta: 10.72(\mathrm{~s}, \mathrm{H}, \mathrm{NH}), 8.24$ (s, 1H, H-2 indole), 8.12 (m, 2H, Ar-H), 7.98-7.02 $(\mathrm{m}, 16 \mathrm{H}, \mathrm{Ar}-\mathrm{H}), 5.55,5.52\left(2 \mathrm{~s}, 4 \mathrm{H}, 2 \mathrm{CH}_{2}\right) ;{ }^{13} \mathrm{C}$ NMR $\left(75 \mathrm{MHz}, \mathrm{DMSO}-d_{6}\right) \delta: 179.91,153.065-110.09$, 69.11, 43.35, 41.04; EI-MS: $m / z(\%): 468\left(\mathrm{M}^{+}, 12\right)$; Anal Calcd for $\mathrm{C}_{31} \mathrm{H}_{24} \mathrm{~N}_{4} \mathrm{O}$ (468.55): C, 79.46; $\mathrm{H}, 5.16$; $\mathrm{N}, 11.96$; found: $\mathrm{C}, 79.46 ; \mathrm{H}, 5.16 ; \mathrm{N}, 11.96$.

5'-(N-Benzoyl-1H-indol-3-yl)-2'-phenyl-2',4'-dihydrospiro(indoline-3,3'-pyrazol)-2-one (14d): Yield 56\%; brown powder; mp 100-2 ${ }^{\circ} \mathrm{C}$; IR $\left(\mathrm{KBr}, \mathrm{cm}^{-1}\right)$ : $3175(\mathrm{NH}), 1798,1975(\mathrm{C}=\mathrm{O}), 1534(\mathrm{C}=\mathrm{C}) ;{ }^{1} \mathrm{H}$ NMR (300 MHz, DMSO- $\left.d_{6}\right) \delta: 10.45$ (s, 1H, NH), 8.45 (s, 1H, H-2 indole), 8.06 (d, 1H, Ar-H), 7.98 (m, 2H, Ar-H), 7.85-7.02 (m, 15H, Ar-H), 5.50 (s, 2H, $\left.\mathrm{CH}_{2}\right) ;{ }^{13} \mathrm{C}$ NMR (75 MHz, DMSO- $\left.d_{6}\right) \delta: 187.60,176.51,151.91$, $143.51,142.24,137.71,136.15,132.61,130.01,128.42,127.91,126.35,122.36,122.21,121.31,116.09,112.14$, 111.81, 68.95, 42.01; EI-MS: $m / z(\%): 482\left(\mathrm{M}^{+}, 6\right)$; Anal Calcd for $\mathrm{C}_{31} \mathrm{H}_{22} \mathrm{~N}_{4} \mathrm{O}_{2}$ (482.53): C, 77.16; $\mathrm{H}, 4.60$; $\mathrm{N}, 11.61$; found: $\mathrm{C}, 77.01 ; \mathrm{H}, 4.52 ; \mathrm{N}, 11.45$.

5'-(N-(2-Chlorobenzoyl)-1H-indol-3-yl)-2'-phenyl-2',4'-dihydrospiro(indoline-3,3'-pyrazol)-2-one (14e): Yield 40\%; reddish-brown powder; $\mathrm{mp} 78-80^{\circ} \mathrm{C}$; IR $\left(\mathrm{KBr}, \mathrm{cm}^{-1}\right)$ : $3176(\mathrm{NH}), 1710,1695(\mathrm{C}=\mathrm{O}), 1620(\mathrm{C}=\mathrm{N})$, $1555(\mathrm{C}=\mathrm{C}), 755(\mathrm{C}-\mathrm{Cl}) ;{ }^{1} \mathrm{H}$ NMR $\left(300 \mathrm{MHz}, \mathrm{DMSO}_{-} d_{6}\right) \delta: 10.72(\mathrm{~s}, 1 \mathrm{H}, \mathrm{NH}), 8.06(\mathrm{~m}, 2 \mathrm{H}, \mathrm{Ar}-\mathrm{H}), 7.92(\mathrm{~d}$, 1H, Ar-H), 7.81-6.92 (m, 15H, Ar-H), 5.21 (s, 2H, CH CH $_{2}$ EI-MS: $\mathrm{m} / z(\%): 516 / 518\left(\mathrm{M}^{+} / \mathrm{M}^{+}+2,13 / 6\right)$; Anal Calcd for $\mathrm{C}_{31} \mathrm{H}_{21} \mathrm{ClN}_{4} \mathrm{O}_{2}$ (516.98): C, 72.02; $\mathrm{H}, 4.09 ; \mathrm{N}, 10.84$; found: $\mathrm{C}, 72.11 ; \mathrm{H}, 4.19 ; \mathrm{N}, 10.73$.

5'-(N-(4-Chlorobenzoyl)-1H-indol-3-yl)-2'-phenyl-2',4'-dihydrospiro(indoline-3,3'-pyrazol)-2-one (14f): Yield 52\%; brown powder; mp 162-4 ${ }^{\circ} \mathrm{C}$; IR $\left(\mathrm{KBr}, \mathrm{cm}^{-1}\right)$ : $3210(\mathrm{NH}), 1797,1685(\mathrm{C}=\mathrm{O}), 1618(\mathrm{C}=\mathrm{N}), 1575$ $(\mathrm{C}=\mathrm{C}), 757(\mathrm{C}-\mathrm{Cl}) ;{ }^{1} \mathrm{H}$ NMR $\left(300 \mathrm{MHz}, \mathrm{DMSO}-d_{6}\right) \delta: 10.72(\mathrm{~s}, 1 \mathrm{H}, \mathrm{NH}), 8.55(1 \mathrm{H}, \mathrm{d}, \mathrm{Ar}-\mathrm{H}), 8.21(\mathrm{~s}, 1 \mathrm{H}$, $\mathrm{H}-2$ indole), 8.01 (m, 2H, Ar-H), 7.92-6.75 (m, 14H, Ar-H), 5.56 (s, 2H, CH $\mathrm{CH}_{2}$; EI-MS: $m / z(\%): 516 / 518$ $\left(\mathrm{M}^{+} / \mathrm{M}^{+}+2,11 / 4\right)$; Anal Calcd for $\mathrm{C}_{31} \mathrm{H}_{21} \mathrm{ClN}_{4} \mathrm{O}_{2}$ (516.98): $\mathrm{C}, 72.02 ; \mathrm{H}, 4.09 ; \mathrm{N}, 10.84$; found: $\mathrm{C}, 71.93 ; \mathrm{H}$, $3.98 ; \mathrm{N}, 10.71$.

5'-(N-(4-Bromo-benzenesulfonyl)-1H-indol-3-yl)-2'-phenyl-2',4'-dihydrospiro(indoline-3,3'-pyrazol)-2-one (14g): Yield 61\%; reddish-brown powder; $\mathrm{mp} 132-4{ }^{\circ} \mathrm{C}$; IR $\left(\mathrm{KBr}, \mathrm{cm}^{-1}\right)$ : $3186(\mathrm{NH}), 1692(\mathrm{C}=\mathrm{O}), 1618$ $(\mathrm{C}=\mathrm{N}), 1555(\mathrm{C}=\mathrm{C}), 1353,1123\left(\mathrm{SO}_{2}\right), 787(\mathrm{C}-\mathrm{Br}) ;{ }^{1} \mathrm{H}$ NMR (300 MHz, DMSO- $\left.d_{6}\right) \delta: 10.54(\mathrm{~s}, 1 \mathrm{H}, \mathrm{NH})$, $8.78(\mathrm{~d}, 1 \mathrm{H}, \mathrm{Ar}-\mathrm{H}), 8.22(\mathrm{~s}, 1 \mathrm{H}, \mathrm{H}-2$ indole), $8.14(\mathrm{~m}, 2 \mathrm{H}, \mathrm{Ar}-\mathrm{H}), 7.88(\mathrm{~d}, 1 \mathrm{H}, \mathrm{Ar}-\mathrm{H}), 7.77-6.87(\mathrm{~m}$, $13 \mathrm{H}, \mathrm{Ar}-\mathrm{H}), 5.25$ (s, $\left.2 \mathrm{H}, \mathrm{CH}_{2}\right) ;{ }^{13} \mathrm{C}$ NMR $\left(75 \mathrm{MHz}, \mathrm{DMSO}-d_{6}\right) \delta: 180.05,152.72,144.35,142.20,139.51$, 138.27, 136.06, 130.25, 128.26, 126.05, 122.31, 121.16, 112.53, 110.04, 112.55, 68.62, 41.16; Anal Calcd for $\mathrm{C}_{30} \mathrm{H}_{21} \mathrm{BrN}_{4} \mathrm{O}_{3} \mathrm{~S}$ (597.48): C, 60.31; H, 3.54; N, 9.38; found: $\mathrm{C}, 60.24 ; \mathrm{H}, 3.41 ; \mathrm{N}, 9.22$.

5'-(N-(4-Chloro-benzenesulfonyl)-1H-indol-3-yl)-2'-phenyl-2',4'-dihydrospiro(indoline-3,3'-pyrazol)-2-one (14h): Yield 54\%; orange powder; $\mathrm{mp} 110-2{ }^{\circ} \mathrm{C}$; IR $\left(\mathrm{KBr}, \mathrm{cm}^{-1}\right)$ : $3175(\mathrm{NH}), 1687(\mathrm{C}=\mathrm{O}), 1618(\mathrm{C}=\mathrm{N})$, $1575(\mathrm{C}=\mathrm{C}), 1355,1132\left(\mathrm{SO}_{2}\right), 775(\mathrm{C}-\mathrm{Cl}) ;{ }^{1} \mathrm{H}$ NMR $\left(300 \mathrm{MHz}, \mathrm{DMSO}-d_{6}\right) \delta: 10.72(\mathrm{~s}, 1 \mathrm{H}, \mathrm{NH}), 8.75(\mathrm{~d}$, 1H, Ar-H), 8.35 (s, 1H, H-2 indole), 8.11 (m, 2H, Ar-H), 7.98 (d, 1H, Ar-H), 7.87-6.75 (m, 13H, Ar-H), 
5.54 (s, 2H, $\mathrm{CH}_{2}$ ); EI-MS: $\mathrm{m} / z$ (\%): 553/555 ( $\left.\mathrm{M}^{+} / \mathrm{M}+2,13 / 5\right)$; Anal Calcd for $\mathrm{C}_{30} \mathrm{H}_{21} \mathrm{ClN}_{4} \mathrm{O}_{3} \mathrm{~S}$ (553.03): $\mathrm{C}$, $65.15 ; \mathrm{H}, 3.83 ; \mathrm{N}, 10.13$; found: $\mathrm{C}, 65.01 ; \mathrm{H}, 3.72 ; \mathrm{N}, 10.02$.

5'-(N-(2-Nitro-benzenesulfonyl)-1H-indol-3-yl)-2'-phenyl-2',4'-dihydrospiro(indoline-3,3'-pyrazol)-2-one (14i): Yield 41\%; reddish-brown powder; $\mathrm{mp} 152-4{ }^{\circ} \mathrm{C}$; IR $\left(\mathrm{KBr}, \mathrm{cm}^{-1}\right)$ : $3177(\mathrm{NH}), 1695(\mathrm{C}=\mathrm{O}), 1620(\mathrm{C}=\mathrm{N})$, $1585(\mathrm{C}=\mathrm{C}), 1353,1127\left(\mathrm{SO}_{2}\right) ;{ }^{1} \mathrm{H}$ NMR $\left(300 \mathrm{MHz}, \mathrm{DMSO}-d_{6}\right) \delta: 10.72(\mathrm{~s}, 1 \mathrm{H}, \mathrm{NH}), 8.57(\mathrm{~d}, 1 \mathrm{H}, \mathrm{Ar}-\mathrm{H})$, $8.15(\mathrm{~s}, 1 \mathrm{H}, \mathrm{H}-2$ indole), $7.92(\mathrm{~m}, 2 \mathrm{H}, \mathrm{Ar}-\mathrm{H}), 7.87(\mathrm{~d}, 1 \mathrm{H}, \mathrm{Ar}-\mathrm{H}), 7.82(\mathrm{~m}, 2 \mathrm{H}, \mathrm{Ar}-\mathrm{H}), 7.53-7.05(\mathrm{~m}, 11 \mathrm{H}$, Ar-H), 5.65 (2s, 2H, CH$)$; EI-MS: $\mathrm{m} / z(\%)$ : $563\left(\mathrm{M}^{+}, 24\right)$; Anal Calcd for $\mathrm{C}_{30} \mathrm{H}_{21} \mathrm{~N}_{5} \mathrm{O}_{5} \mathrm{~S}$ (563.58): C, 63.93; $\mathrm{H}, 3.76 ; \mathrm{N}, 12.43$; found: $\mathrm{C}, 63.75 ; \mathrm{H}, 3.61 ; \mathrm{N}, 12.35$.

\subsubsection{General Procedure for Synthesis of Quinoline-4-carboxylic acids 15a, $\mathbf{b}$}

To a solution of isatin $(\mathbf{1})(10 \mathrm{mmol})$ in ethanol $(10 \mathrm{~mL})$, a solution of potassium hydroxide $(10$ $\mathrm{mL}, 33 \%$ ) was added, and the mixture was heated under reflux for $10 \mathrm{~min}$. After cooling, the reaction mixture was acidified to $\mathrm{pH} 2-3$ using $0.38 \mathrm{~mL}$ of concentrated hydrochloric acid. To the reaction mixture, compound $\mathbf{2 a}$ and $3 \mathbf{a}(10 \mathrm{mmol})$ were added and then heated under reflux for 6-12 h. After cooling, the reaction mixture was poured into ice-water, and the solid formed was filtered off, washed with water, air-dried and crystallized from ethanol.

3-(6-Hydroxy-4-methoxybenzofuran-5-yl)quinoline-4-carboxylic acid (15a): Yield 70\%; pale yellow powder; mp 217-9 ${ }^{\circ} \mathrm{C}$; IR (KBr, cm $\left.{ }^{-1}\right)$ : $3450(\mathrm{OH}), 1710$ (C=O), 1595 (C=C), 1135, 1029 (C-O-C); ${ }^{1} \mathrm{H}$ NMR (300 MHz, DMSO- $\left.d_{6}\right) \delta: 11.85(\mathrm{~s}, 2 \mathrm{H}, 2 \mathrm{OH}), 8.47(\mathrm{~d}, 1 \mathrm{H}, \mathrm{Ar}-\mathrm{H}), 8.30(\mathrm{~s}, 1 \mathrm{H}, \mathrm{Ar}-\mathrm{H}), 8.13(\mathrm{~d}, 1 \mathrm{H}$, Ar-H), $7.82(\mathrm{~m}, 3 \mathrm{H}, \mathrm{Ar}-\mathrm{H}), 7.17(\mathrm{t}, 1 \mathrm{H}, \mathrm{Ar}-\mathrm{H}), 6.91(\mathrm{~s}, 1 \mathrm{H}, \mathrm{Ar}-\mathrm{H}), 4.51\left(\mathrm{~s}, 3 \mathrm{H}, \mathrm{OCH}_{3}\right) ;{ }^{13} \mathrm{C} \mathrm{NMR}(75 \mathrm{MHz}$, DMSO- $\left.d_{6}\right) \delta:$ 203.01, 167.53, 156.93, 155.62, 146.83, 143.52, 136.14, 128.61, 127.78, 125.38, 122.98, 122.09, 112.18, 110.33, 105.35, 93.35, 62.00; EI-MS: $\mathrm{m} / z(\%): 335\left(\mathrm{M}^{+}, 33\right)$; Anal Calcd for $\mathrm{C}_{19} \mathrm{H}_{13} \mathrm{NO}_{5}$ (335.31): $\mathrm{C}$, $68.06 ; \mathrm{H}, 3.91 ; \mathrm{N}, 4.18$; found: $\mathrm{C}, 67.91 ; \mathrm{H}, 3.84 ; \mathrm{N}, 4.07$.

3-(6-Hydroxy-4,6-dimethoxybenzofuran-5-yl)quinoline-4-carboxylic acid (15b): Yield 53\%; yellow powder; mp 275-7 ${ }^{\circ} \mathrm{C}$; IR $\left(\mathrm{KBr}, \mathrm{cm}^{-1}\right)$ : $3510(\mathrm{OH}), 1709$ (C=O), 1587 (C=C), 1155, 1031 (C-O-C); ${ }^{1} \mathrm{H}$ NMR (300 MHz, DMSO-d 6 ) $\delta: 12.31(\mathrm{~s}, 2 \mathrm{H}, 2 \mathrm{OH}), 8.42(\mathrm{~d}, 1 \mathrm{H}, \mathrm{Ar}-\mathrm{H}), 8.07$ (d, 1H, Ar-H), $7.91(\mathrm{~s}, 1 \mathrm{H}, \mathrm{Ar}-\mathrm{H})$, 7.66-7.58 (m, 2H, Ar-H), 7.16 (s, 2H, Ar-H), 3.96, $3.79\left(2 \mathrm{~s}, 6 \mathrm{H}, 2 \mathrm{OCH}_{3}\right) ;{ }^{13} \mathrm{C}$ NMR $\left(75 \mathrm{MHz}, \mathrm{DMSO}-d_{6}\right) \delta$ : 200.93, 161.33, 152.70, 147.23, 143.61, 138.51, 132.71, 128.35, 126.90, 124.44, 123.66, 105.91, 61.50, 59.25; EI-MS: $m / z(\%): 365\left(\mathrm{M}^{+}, 33\right)$; Anal Calcd for $\mathrm{C}_{20} \mathrm{H}_{15} \mathrm{NO}_{6}$ (365.34): $\mathrm{C}, 65.75 ; \mathrm{H}, 4.14 ; \mathrm{N}, 3.83$; found: $\mathrm{C}$, $65.61 ; \mathrm{H}, 4.03 ; \mathrm{N}, 3.65$.

\subsection{Biological Assays}

\subsubsection{Antimicrobial Evaluation}

The antimicrobial activity of target compounds were evaluated to be in vitro against a variety of pathogenic microorganisms, namely Staphylococcus aureus (ATCC 6538), Bacillus subtilis (ATCC 6633) (Gram-positive bacteria), Pseudomonas areuginosa (ATCC 27853), Escherichia coli (DSMZ 1058) (Gram-negative bacteria), Candida albicans (ATCC 10231), Saccharomyces cerevisiae (ATCC 9080) (Yeast) and Aspergillus niger (NRRL A-326) (Fungi) using the disk diffusion method [31] at a single dose of 20 $\mu \mathrm{g}$. The microorganisms were served and obtained from the Microbial Biotechnology Department, National Research Center, Giza, Egypt. Amphotericin, amoxicillin and ciprofloxacin were used as reference drugs (Oxoid ${ }^{\mathrm{TM}}$ Disks). The tested compounds 11a-c, 12a-c, 13a-i, 14a-i and 15a,b were dissolved in dimethylsulphoxide (DMSO) at a concentration of $1 \mathrm{mg} / \mathrm{mL}$. Aliquots of $20 \mu \mathrm{l}$ were soaked on filter paper discs $(6 \mathrm{~mm})$ and dried at room temperature under sterilized conditions. The paper discs were placed on inoculated agar plats and then incubated for $24 \mathrm{~h}$ at $37^{\circ} \mathrm{C}$ for bacterial strains and after $48-72 \mathrm{~h}$ incubation at $30^{\circ} \mathrm{C}$ for fungi. Both bacterial and yeast strains were grown on nutrient agar medium (g/l): beef extract, 3 ; peptone, 10 and agar, 20 at $\mathrm{pH}$ of 7.2. The fungal strain was grown on Czapek-Dox medium (g/l): sucrose, 30; $\mathrm{NaNO}_{3}, 3 ; \mathrm{MgSO}_{4} .7 \mathrm{H}_{2} \mathrm{O}, 0.5 \mathrm{l} ; \mathrm{KCl}, 0.5 ; \mathrm{FeSO}_{4}, 0.01 ; \mathrm{K}_{2} \mathrm{HPO}_{4}, 1$ and agar, 20 at $\mathrm{pH}$ of 6.0. 


\subsubsection{Antioxidant Evaluation}

The free radical scavenging activity (RSA) was assessed spectrophotometically at $517 \mathrm{~nm}$ via decoloration of the solution of the DPPH (1,1-diphenyl-2-picrylhydrazyl) radical according to Brand-Williams et al. 1995 [32]. DPPH solution was prepared by dissolving of $20 \mathrm{mg}$ of DPPH in one liter of dimethylsulphoxide (DMSO). A freshly prepared DPPH solution was used for the assay. Each of the tested compounds 11a-c, 12a-c, 13a-i, 14a-i and 15a,b were dissolved in DMSO $(1 \mathrm{mg} / \mathrm{mL})$. A volume of $20 \mu \mathrm{g} / \mathrm{l}$ of a DMSO stock solution of the test compounds was added to $2 \mathrm{~mL}$ of freshly prepared DPPH in DMSO solution. The mixtures were shaken in a vortex (2500 rpm) for $1 \mathrm{~min}$ and then left to stand for 15, 30, 45 and $60 \mathrm{~min}$ in the dark room. The absorbance was measured at 517 $\mathrm{nm}$ against blank using UV visible spectrophotometer 2401 PC (Shimadzu, Kyoto, Japan). Lower absorbance of the reaction mixture indicated higher free radical scavenging activity was analyzed from the graph plots of the inhibition percentage against the compound concentration. The experiment was carried out in triplicate and averaged. The scavenging activity was calculated according to the following formula:

$$
\text { Scavenging ability }(\%)=\left(\mathrm{A}_{517} \text { of control }-\mathrm{A}_{517 \text { of sample } /} \mathrm{A}_{517 \text { of control }}\right) \times 100
$$

\subsubsection{Anticancer Evaluation}

\section{Cell Culture}

MCF-7 (human breast cancer), HCT-116 (human colon cancer) and HepG2 (human liver cancer) cell lines were obtained from Karolinska Institute, Stockholm, Sweden. All cells were maintained in RPMI 1640 medium. The media were supplemented with $10 \%$ heat-inactivated fetal bovine serum plus $1 \%$ antibiotic-antimycoticmixture $(10,000 \mathrm{U} / \mathrm{mL}$ of potassium penicillin, $10,000 \mu \mathrm{g} / \mathrm{mL}$ of streptomycin sulfate, $25 \mu \mathrm{g} / \mathrm{mL}$ of amphotericin B and $1 \%$ of $L$ glutamine (Biowest, USA)). BJ-1 of a human skin fibroblast derived from normal foreskin was obtained from ATCC ${ }^{\circledR}$ CRL-2522 ${ }^{\mathrm{TM}}$ as a frozen ampoule with about $1 \times 10^{6}$ cells per $1 \mathrm{ml}$ volume. BJ- 1 was maintained in MEM with $2 \mathrm{mM}$ of $L$-glutamine and Earle's salts medium.

\section{MTT Cytotoxicity Assay}

Cell viability was studied using the MTT 3-(4,5-dimethylthiazol-2-yl)-2,5-diphenyl-tetrazolium bromide (Bio Basic Canada Inc. Toronto, Canada) assay [33]. The steps were executed in a sterile laminar air flow cabinet biosafety class II level (Baker, SG403INT; Sanford, ME, USA). All incubations were carried out at $37{ }^{\circ} \mathrm{C}$ in a $5 \% \mathrm{CO}_{2}$ incubator under a humidified atmosphere of $95 \%$ (Sheldon, TC2323; Cornelius, OR, USA). Cells were seeded into 96-well microtiter plastic plates at a concentration of $\left(10^{4}\right.$ cells/well $)$ and allowed to adhere for $24 \mathrm{~h}$. The medium was aspirated and then added to the cells with the test compounds $11 \mathrm{a}-\mathrm{c}, 12 \mathrm{a}-\mathrm{c}, 13 \mathrm{a}-\mathrm{i}, 14 \mathrm{a}-\mathrm{i}$ and $15 \mathrm{a}, \mathrm{b}$ at a single dose of $100 \mu \mathrm{g} / \mathrm{mL}$ in DMSO. After incubation of the medium for $48 \mathrm{~h}, 40 \mu \mathrm{L}$ of MTT salt $(2.5 \mu \mathrm{g} / \mathrm{mL})$ was added to each well and then incubated for an additional $4 \mathrm{~h}$. To stop the reaction and dissolve any formed formazan crystals, $200 \mu \mathrm{L}$ of $10 \%$ sodium dodecyl sulfate (SDS) were added to each well and incubated overnight at $37^{\circ} \mathrm{C}$. The amount of formazan product was measured at $595 \mathrm{~nm}$ with a reference wavelength of 690 $\mathrm{nm}$ as a background using a microplate reader (Bio-Rad Laboratories, model 3350, California, USA). For the untreated cells (negative control), the medium was added instead of the tested compounds. A positive control adrinamycin ${ }^{\circledR}$ (doxorubicin, $\mathrm{Mr}=579.9$ ) (Pharmacia India Pvt Ltd. Gurgaon, Haryana 122001, India) was used as a known cytotoxic natural agent giving $100 \%$ inhibition. Dimethylsulfoxide (DMSO) was the vehicle used for dissolution of the testing compound, and its final concentration on the cells was less than $0.2 \%$. At the same dilution, the solvent concentration was the same for all drugs and between the control and drug treatments. The concentration required for $50 \%$ inhibition of cell viability $\left(\mathrm{IC}_{50}\right)$ was calculated for the potent compounds that showed preliminary cytotoxic effects at $100 \mu \mathrm{g} / \mathrm{mL}$ by applying various concentrations of $0,10,15,20,25,30,40$ and $50 \mu \mathrm{g} / \mathrm{mL}$ (three replicates 
per concentration group) of the tested compounds and employing the probit analysis method using a simple $t$-test (SPSS statistical analysis software package/version 11.0, SPSS Inc. (IL), Chicago, USA).

\subsection{Apoptosis Assay}

The cellular apoptosis protein markers were analyzed after treatment with the $\mathrm{IC}_{50}$ of $11 \mathrm{a}, 11 \mathrm{~b}, 12 \mathrm{a}$, $12 b$ and $13 c$, which were characterized for their relevant antiproliferative activity previously. Briefly, cells (HepG2 and HCT) were seeded at a concentration of 1.2-1.8 $\times 10^{3}$ cells/well in 6-well plates. After 48-h treatment, the collected cells were lysed and centrifuged at $10,000 \mathrm{rpm}$ for $20 \mathrm{~min}$ at $4{ }^{\circ} \mathrm{C}$. The protein concentration was measured in the supernatant by Bradford protein assay [34]. Volume containing $50 \mathrm{mg}$ of total protein was incubated with $5 \mathrm{~mL}$ of caspase substrate in $100 \mathrm{~mL}$ of the reaction buffer at $37^{\circ} \mathrm{C}$ for $1 \mathrm{~h}$ in the dark. Caspase- 3 activity was determined by a microplate reader at $405 \mathrm{~nm}$ using a caspase-3 colorimetric assay kit (Abcam) according to the manufacturer's instructions [23]. In vitro protein level quantitative measurement of apoptotic marker p53, Bcl-2-associated X (Bax) and antiapoptotic marker B-cell lymphoma-2 (Bcl-2) in cell lysate were assessed by Enzyme-Linked Immunosorbent Assay Simple Step ELISA ${ }^{\circledR}$ (ab199080, ab119506 and ab171571; Abcam) according to the manufacturer's instructions [35-37].

Data are presented as means \pm SD. Individual groups were compared using the two-tailed independent Student's $t$-test. Multiple group comparisons were carried out using one-way analysis of variance (ANOVA) followed by the Tukey-Kramer test for post-hoc analysis.

Author Contributions: Conceptualization and data interpretation, H.M.A.-S.; methodology, evaluation and validation, H.M.A.-S. A.N. A.A.F.S. M.S.E. S.A.A. M.E.E. and M.A.M.A.-S.; writing-original draft preparation, E.R.E.-S.; writing-review and editing the final draft, M.A.M.A.-S. and Y.A.A.-S. and funding acquisition, M.A.M.A.-S. and Y.A.A.-S. All authors have read and agreed to the published version of the manuscript.

Funding: This research received no external funding.

Conflicts of Interest: The authors declare no conflicts of interest.

\section{References}

1. Sagar, S.; Esau, L.; Moosa, B.; Khashab, N.M.; Bajic, V.B.; Kaur, M. Cytotoxicity and apoptosis induced by a plumbagin derivative in estrogen positive MCF-7 breast cancer cells. Anti-Cancer Agents Med. Chem. 2014, 14, 170-180. [CrossRef] [PubMed]

2. Plackal, B.; George, A.; Abrahamse, H. A Review on Novel Breast Cancer Therapies: Photodynamic Therapy and Plant Derived Agent Induced Cell Death Mechanisms. Anti-Cancer Agents Med. Chem. 2016, 16, 793-801. [CrossRef] [PubMed]

3. Padma, V.V. An overview of targeted cancer therapy. BioMedicine 2015, 5, 19. [CrossRef] [PubMed]

4. Hassan, M.; Watari, H.; AbuAlmaaty, A.; Ohba, Y.; Sakuragi, N. Apoptosis and molecular targeting therapy in cancer. BioMed. Res. Int. 2014, 2014, 150845. [CrossRef]

5. Ghobrial, I.M.; Witzig, T.E.; Adjei, A.A. Targeting Apoptosis Pathways in Cancer Therapy. CA Cancer J. Clin. 2005, 55, 178-194. [CrossRef] [PubMed]

6. Zhang, Q.; Ma, S.; Liu, B.; Liu, J.; Zhu, R.; Li, M. Chrysin induces cell apoptosis via activation of the p53/Bcl-2/caspase-9 pathway in hepatocellular carcinoma cells. Exp. Ther. Med. 2016, 12, 469-474. [CrossRef]

7. He, Z.; Ma, W.-Y.; Hashimoto, T.; Bode, A.M.; Yang, C.S.; Dong, Z. Induction of apoptosis by caffeine is mediated by the p53, Bax, and Caspase 3 pathways. Cancer Res. 2003, 63, 4396-4401.

8. Medvedev, A.; Buneeva, O.; Gnedenko, O.; Ershov, P.; Ivanov, A. Isatin, an endogenous nonpeptide biofactor: A review of its molecular targets, mechanismsof actions, and their biomedical implications. BioFactors 2018, 44, 95-108. [CrossRef]

9. Singh, G.S.; Desta, Z.Y. Isatins as privileged molecules in design and synthesis of spiro-fused cyclic frameworks. Chem. Rev. 2012, 112, 6104-6155. [CrossRef]

10. Ziarani, G.M.; Gholamzadeh, P.; Lashgari, N.; Hajiabbasia, P. Oxindole as starting material in organic synthesis. ARKIVOC 2013, 470-535. [CrossRef] 
11. Kozielewicz, P.; Paradowska, K.; Eric, S.; Wawer, I.; Zloh, M. Insights into mechanism of anticancer activity of pentacyclic oxindole alkaloids of Uncaria tomentosa by means of a computational reverse virtual screening and molecular docking approach. Monatsh. Chem. 2014, 145, 1201-1211. [CrossRef]

12. Whatmore, J.L.; Swann, E.; Barraja, P.; Newsome, J.J.; Bunderson, M.; Beall, H.D.; Tooke, J.E.; Moody, C.J. Comparative study of isoflavone, quinoxaline and oxindole families of anti-angiogenic agents. Angiogenesis 2002, 5, 45-51. [CrossRef] [PubMed]

13. Giménez, D.G.; Prado, G.E.; Rodríguez, S.T.; Arche, F.A.; La Puerta, R. Cytotoxic effect of the pentacyclic oxindole alkaloid mitraphylline isolated from Uncaria tomentosa bark on human Ewing's sarcoma and breast cancer cell lines. Planta Med. 2010, 76, 133-136. [CrossRef] [PubMed]

14. Yu, B.; Yu, D.-Q.; Liu, H.-M. Spirooxindoles: Promising scaffolds for anticancer agents. Eur. J. Med. Chem. 2015, 97, 673-698. [CrossRef]

15. Gupta, A.K.; Bharadwaj, M.; Kumar, A.; Mehrotra, R. Spiro-oxindoles as a Promising class of small molecule inhibitors of p53-MDM2 interaction useful in targeted cancer therapy. Top. Curr. Chem. 2017, 375, 3. [CrossRef]

16. Eldehna, W.M.; Almahli, H.; Al-Ansary, G.H.; Ghabbour, H.A.; Aly, M.H.; Ismael, O.E.; Al-Dhfyan, A.; Abdel-Aziz, H.A. Synthesis and in vitro anti-proliferative activity of some novel isatins conjugated with quinazoline/phthalazine hydrazines against triple-negative breast cancer MDA-MB-231 cells as apoptosis inducing agents. J. Enzyme Inhib. Med. Chem. 2017, 32, 600-613. [CrossRef]

17. Moghaddam, M.N.; Jalal, R.; Zeraatkar, Z. Synthesis and antiproliferative and apoptosis-inducing activity of novel 3-substituted-3-hydroxy-2-oxindole compounds. In Vitro Cell Dev. Biol. Anim. 2018, 54, 61-70. [CrossRef]

18. Bacher, N.; Tiefenthaler, M.; Sturm, S.; Stuppner, H.; Ausserlechner, M.J.; Kofler, R.; Konwalinka, G. Oxindole alkaloids from Uncaria tomentosa induce apoptosis in proliferating, G0/G1-arrested and bcl-2-expressing acute lymphoblastic leukaemia cells. Br. J. Haematol. 2006, 132, 615-622. [CrossRef]

19. Schonberg, A.; Sina, A. Khellin and allied compounds. J. Am. Chem. Soc. 1950, 72, 1611-1615. [CrossRef]

20. Schonberg, A.; Badran, N.; Starkowsky, N.A. Furo-chromones and -coumarins. VII. Degradation of visnagin, khellin and related substances; experiments withchromic acid and hydrogen peroxide; and a synthesis of Eugenitin. J. Am. Chem. Soc. 1953, 75, 4992-4995. [CrossRef]

21. Spath, E.; Gruber, W. Die constitution des khelline aus Ammi visnaga. I. Metteil uber naturliche chromone. Berichte 1938, 71B, 106.

22. Mndzhoyan, A.L.; Papayan, G.L.; Zhuruli, L.D.; Karagezyan, G.; Galstyan, L.S.; Sarafyan, V.G. Synthesis and biological study of hydrazinohydrazones of indole aldehydes and ketons series. Arm. Khim. Zh. 1970, 72, $11189 f$.

23. Ottoni, O.; Cruz, R.; Alves, R. Efficient and simple methods for the introduction of the sulfonyl, acyl and alkyl protecting groups on the nitrogen of indole and its derivatives. Tetrahedron 1998, 54, 13915-13928. [CrossRef]

24. Sangshetti, J.N.; Zambare, A.S.; Gonjari, I.; Shinde, D.B. Pfitzinger reaction in the synthesis of bioactive compounds-A review. Mini-Revi. Org. Chem. 2014, 11, 225-250. [CrossRef]

25. Elmore, S. Apoptosis: A review of programmed cell death. Toxicol. Pathol. 2007, 35, 495-516. [CrossRef]

26. Alenzi, F.Q.; Alenazi, B.Q.; Al-Anazy, F.H.; Mubaraki, A.M.; Salem, M.L.; Al-Jabri, A.A.; Lotfy, M.; Bamaga, M.S.; Alrabia, M.W.; Wyse, R.K. The role of caspase activation and mitochondrial depolarisation in cultured human apoptotic eosinophils. Saudi. J. Biol. Sci. 2010, 17, 29-36. [CrossRef]

27. Lakhani, S.A.; Masud, A.; Kuida, K.; Porter, G.A.; Booth, C.J.; Mehal, W.Z.; Inayat, I.; Flavell, R.A. Caspases 3 and 7: Key mediators of mitochondrial events of apoptosis. Science 2006, 311, 847-851. [CrossRef]

28. Wolf, B.B.; Schuler, M.; Echeverri, F.; Green, D.R. Caspase-3 is the primary activator of apoptotic DNA fragmentation via DNA fragmentation factor-45/inhibitor of caspase-activated DNase inactivation. J. Biol. Chem. 1999, 274, 30651-30656. [CrossRef]

29. Oren, M. Regulation of the p53 tumor suppressor protein. J. Biol. Chem. 1999, 274, 36031-36034. [CrossRef]

30. Degenhardt, K.; Chen, G.; Lindsten, T.; White, E. BAX and BAK mediate p53 independent suppression of tumorigenesis. Cancer Cell 2002, 2, 193-203. [CrossRef]

31. Bauer, A.W.; Kirby, W.M.; Sherris, J.C.; Truck, M. Antibiotic susceptibility testing by a standardized single disk method. Am. J. Clin. Pathol. 1966, 45, 493-496. [CrossRef] [PubMed]

32. Brand-Williams, W.; Cuvelier, M.E.; Berset, C. Use of a free radical method to evaluate antioxidant activity. Lebensm. Wiss. Technol. 1995, 28, 25-30. [CrossRef] 
33. Mosmann, T. Rapid colorimetric assays for cellular growth and survival: Application to proliferation and cytotoxicity assays. J. Immunol. Methods 1983, 65, 55-63. [CrossRef]

34. Aboul-Soud, M.A.M.; Al-Amri, M.Z.; Kumar, A.; Al-Sheikh, Y.A.; Ashour, A.E.; El-Kersh, T.A. Specific Cytotoxic Effects of Parasporal Crystal Proteins Isolated from Native Saudi Arabian Bacillus thuringiensis Strains against Cervical Cancer Cells. Molecules 2019, 24, 506. [CrossRef] [PubMed]

35. Bradford, M.M. A rapid and sensitive method for the quantitation of microgram quantities of protein utilizing the principle of protein-dye binding. Anal. Biochem. 1976, 72, 248-254. [CrossRef]

36. Hirao, A.; Kong, Y.Y.; Matsuoka, S.; Wakeham, A.; Ruland, J.; Yoshida, H.; Liu, D.; Elledge, S.J.; Mak, T.W. DNA damage-induced activation of p53 by checkpoint kinase Chk2. Science 2000, 287, 1824-1827. [CrossRef]

37. Chen, C.J.; Makino, S. Murine coronavirus replication induces cell cycle arrest in G0/G1 phase. J. Virol. 2004, 78, 5658-5669. [CrossRef]

Sample Availability: Samples of the synthesized spiro pyrazole-oxindole compounds are available from the authors upon request and MTA formulation.

(C) 2020 by the authors. Licensee MDPI, Basel, Switzerland. This article is an open access article distributed under the terms and conditions of the Creative Commons Attribution (CC BY) license (http://creativecommons.org/licenses/by/4.0/). 